\title{
O SEMINÁRIO DE NOSSA SENHORA DA BOA MORTE: MARIANA, MINAS GERAIS, 1750-1850
}

\author{
Sérgio Cristóvão Selingardi ${ }^{1}$
}

João Virgílio Tagliavini ${ }^{2}$

\section{RESUMO}

Um trabalho histórico e historiográfico, fruto da pesquisa de garimpagem nos arquivos da Arquidiocese de Mariana, trabalho de orientando historiador, com o auxílio de orientador especialista em seminários menores de modelo tridentino. O objetivo do artigo parte de uma dissertação de mestrado apresentada no Programa de Pós-Graduação em Educação na UFSCar, é o resgate minucioso de um século de história do Seminário Nossa Senhora da Boa Morte de Mariana, Minas Gerais, local de formação do Clero Mineiro, entre 1750 e 1850. Trata-se de mais uma importante obra da educação brasileira fundada pelos jesuítas, cuja continuidade ficou sob a responsabilidade de outras congregações. $\mathrm{O}$ autor fez o trabalho desde um lugar privilegiado, pois cursou história no próprio prédio onde outrora funcionara o seminário e teve acesso aos arquivos da Arquidiocese, e, portanto, às fontes primárias do seminário, o que dá originalidade e garante o ineditismo do trabalho. Torna-se indispensável a leitura deste artigo aos estudiosos da educação brasileira.

Palavras chave: Seminário menor. Formação do clero. Seminário de Mariana. Seminário Tridentino.

\section{THE NOSSA SENHORA DA BOA MORTE SEMINARY: MARIANA, MINAS GERAIS, 1750-1850}

\section{ABSTRACT}

This is a historical and historiographical work resulting from a careful research in the archives of the Archdiocese of Mariana. It was developed by a student/historian, and assisted by a supervisor who is a specialist in the tridentine-style minor seminaries. This work aims to minutely recover hundred years of history of the Nossa Senhora da Boa Morte Seminary in Mariana, Minas Gerais, where the Clergy of Minas had its formation, between 1750 and 1850. This seminary, founded by the Jesuits, is of paramount importance to the Brazilian education, and its preservation has been under the responsibility of other congregations. The author has had a privileged position, because he majored in History at the building where the seminary used to work. It certainly brings accuracy, originality and uniqueness to his research. Thus, it is vital that this article is read by all the scholars of Brazilian Education.

Keywords: Minor Seminary. Formation of the Clergy. Seminary of Mariana. Tridentine Seminary.

\section{O Concílio de Trento e a criação dos seminários}

Com o propósito de reformar o clero, o Concílio de Trento, deu início à reorganização das escolas católicas, dos mosteiros e conventos, resolveu estabelecer seminários ${ }^{3}$, procurando satisfazer: “(...) a necessidade de que os que se destinam aos ministérios do altar sejam (...) preservados do contágio do mundo e (...) iniciados na formação em piedade e ciência requeridas pela sua alta missão (...)." (FREITAS, 1979, p.29). Assim, os seminários diocesanos seriam destinados a educar religiosamente e a instruir nas disciplinas eclesiásticas as novas levas de sacerdotes, sob a justificativa de que se a idade juvenil não for bem orientada, é conduzida aos prazeres do mundo.

O supracitado decreto exige para a admissão no seminário que: os alunos tenham a idade 
mínima de doze anos; sejam filhos de legítimo matrimônio; saibam ler e escrever convenientemente; e sejam da cidade, diocese ou província (eclesiástica). Devem ser principalmente oriundos das camadas menos favorecidas da sociedade, e serão recebidos gratuitamente, alimentados e educados. Todavia, os ricos não são excluídos, desde que se sustentem às suas expensas e demonstrem o desejo de servir a Deus e à Igreja Católica. Mas, não é preciso que: “(...) queiram absolutamente abraçar o estado eclesiástico. Basta não sejam aversos ( ic ) a este instituto e se comportem honestamente. Aliás, ciência certa da própria vocação de nenhum aluno se poderia exigir (...).” (FREITAS, 1979, p.35)

\section{Antecedentes da fundação do Seminário de Nossa Senhora da Boa Morte}

Apesar de que o Brasil tenha recebido plena e simplesmente o Concílio de Trento, verifica-se um atraso na instituição dos seminários diocesanos. Porém, segundo Freitas (1979), essa demora não se refere ao tempo que compreende a promulgação do Concílio e o aparecimento dos primeiros colégios diocesanos destinados à formação sacerdotal, mas sim, ao espaço entre a criação da diocese e a do seminário.

De modo geral, esse atraso está relacionado, conforme Freitas (1979), entre outros fatores, com: a pobreza das dioceses, embora os bispos pudessem contar com as esmolas dos fiéis para os seminários; e a exígua contribuição financeira, por parte do Grão-Mestre, para a ereção e sustento dos seminários.

O primeiro seminário diocesano do Brasil foi fundado no Rio de Janeiro, em 1739, e denominado Seminário de São José. Considerando que a diocese da referida cidade foi criada em 1676, nota-se um período de sessenta e três anos, entre a criação do bispado e a fundação do seminário. Segue-se na ordem cronológica a criação do Seminário de Belém do Grão-Pará, em 1749. Neste caso, há um espaço de trinta anos, pois essa diocese foi criada em 1719. O terceiro seminário diocesano é o de Nossa Senhora da Boa Morte, de Mariana. Essa instituição foi a que mais satisfez, nesse caso, as determinações tridentinas, pois apenas cinco anos separam a criação da diocese (1745) e a do seminário (1750).

Antes da Independência do Brasil ainda foram criados: o Seminário de Nossa Senhora das Graças, na diocese de Olinda, em 1800; e o de São Dâmaso, na Arquidiocese da Bahia, em 1815. No primeiro caso, verifica-se um espaço de mais de cento e vinte anos entre a fundação do bispado (1676) e a do seminário; no segundo, tal espaço é de mais de duzentos e cinquenta anos, pois, a diocese da Bahia foi criada em 1551.

Pela exposição acima, pode se inferir que o século XVIII marca o início da era dos seminários episcopais no Brasil. Nessa empresa, destacam-se as peregrinações do padre jesuíta Gabriel Malagrida pelo norte e nordeste, tomando a decisão de erigir casas para a formação sacerdotal da juventude. Para isso, obtém autorização dos soberanos portugueses para a fundação de seminários: “(...) O Alvará de 1751 conferia-lhe o poder de erigir seminários em qualquer parte da América (...).” (AZZI, 1977, p.198)

\section{A fundação do Seminário de Nossa Senhora da Boa Morte}

Como foi visto, em 1745, através do Moto Proprio Candor lucis aeternae, do papa Bento XIV, é criada a diocese de Mariana, no interior do espírito tridentino: “(...) Queremos ainda que, quanto antes (...) que ponhas particular empenho em dotar a (...) diocese de um seminário, como o exige o Sagrado Concílio de Trento (...).",

Nesse compasso, D. Frei Manuel da Cruz, nomeado para administrar o recém-criado bispado de Mariana, mas ainda na condição bispo do Maranhão, em carta endereçada a D. João $\mathrm{V}$, rei de Portugal, manifestou seu propósito de fundar um seminário na nova diocese:

Foi V. Maj. Servido recomendar-me eficazmente que cuidasse muito em fundar nesta cidade (São Luís do Maranhão) um seminário e que aplicasse para ele o espólio do 
Bispo defunto, meu antecessor, Dom Frei José Delgarte (...) e como no (bispado) de Mariana é ainda mais precisa a fundação de um seminário pelas grandes despesas que fazem os moradores daquela Capitania em mandarem seus filhos aos estudos no Rio de Janeiro e da (sic) Bahia, levo grande desejo de fundar também naquela cidade um seminário para o que roguei ao Padre Missionário Gabriel Malagrida para ir fazer Missão naquele bispado (...) Espero na grande piedade de V. Maj. me não falte com a sua real proteção para estas duas fundações, assim do bispado, como do Seminário (...). ${ }^{5}$

Pela leitura do trecho acima pode-se verificar que a instrução em Minas, era precária nesse período, pois seus moradores se viam obrigados a mandar seus filhos para estudar fora da Capitania. Segundo Carrato (1968), o apelo do papa Bento XIV para que se criasse um seminário na nova diocese se justificava por sua intenção de formar cleros nativos. Assim, um seminário em Mariana formaria sacerdotes da terra, conforme o desejo do pontífice, ao mesmo tempo que teria o propósito de " (...) sanar a rudeza de meninos incultos (...).",

Como resposta, o soberano envia ao bispo, D. Frei Manuel da Cruz, uma Ordem Régia autorizando a criação do seminário. Daí observa-se a ingerência do poder temporal nos assuntos de ordem religiosa, atestando a vigência do regime do padroado. Sob este, de acordo com Carrato (1968), o bispo tem aparente autonomia no cumprimento de sua missão pastoral. Contudo, se o mesmo prelado dá um passo adiante, vê-se nas malhas dos imperativos regalistas do supracitado regime, que fazia do clero simples funcionário público do monarca:

(...) Faço saber a vós Reverendo Bispo da Cidade de Mariana, que se viu o que me
representaste sobre a precisão que havia nesse Bispado, de se fundar um Seminário
pelas grandes despesas que faziam os Moradores dessa Capitania em mandarem seus
filhos aos estudos do Rio de Janeiro e Bahia, para cuja fundação rogareis ao Padre
Gabriel Malagrida, da Companhia de Jesus, passasse a fazer Missão nesse Bispado,
porque a experiência tinha mostrado em toda América que as suas doutrinas e exemplo
não só moviam aos ouvintes a emendar a vida, mas tão bem a oferecerem esmolas para
obras pias, esperando que eu não faltasse com a minha Real Proteção para esta fundação
e para tudo mais que entenderes é necessário para o bom regime dessa Diocese: o que
visto; Fui servido por resolução (...) em consulta do meu Conselho Ultramarino
conformar-me com o que referis (...).

Apesar de confirmado por Bento XIV, em 1745, o novo bispo chega à Mariana somente em 1748, depois de uma longa viagem pelos sertões. E, uma vez instalado na nova diocese, D. Frei Manuel da Cruz, entre outras tarefas, se esforça para a realização do sonho que acalentava ainda no Maranhão: um seminário na nova diocese.

No dia 20 de dezembro de 1750, o primeiro bispo de Mariana fundou, nesta cidade, o Seminário de Nossa Senhora da Boa Morte. Embora a data oficial da fundação seja a mencionada acima, essa instituição já se encontrava em funcionamento desde o mês de agosto do referido ano. ${ }^{8}$

De acordo com Trindade (1953), o Seminário de Nossa Senhora da Boa Morte é o estabelecimento de instrução e educação mais antigo de Minas e, por um período de mais de meio século, o único a instruir os filhos das famílias mineiras. Porém, segundo Veiga (1998), o Recolhimento de Macaúbas ${ }^{9}$ constitui o instituto de educação mais antigo de Minas. Antes de 1730, conforme Carrato (1968) já existia uma escola conventual em Macaúbas, embora apenas no último quartel do século XVIII que ali floresceria uma instituição de educação de meninas. Entretanto, não havia espaço suficiente para as instalações de ensino: “(...) cifrava-se em algumas noções de primeiras letras, doutrina cristã e trabalhos de agulha (...).” (SOUZA, 1930, p.381). Somente no século seguinte foi fundado o Colégio de Macaúbas, estabelecimento tradicional na educação feminina nas Minas.

Também é questionável a afirmação de que o estabelecimento fundado por D. Frei Manuel da Cruz foi o único que deu instrução, por mais de meio século, aos filhos de Minas, pois, conforme Carrato (1968) ainda no início da segunda metade do século XVIII, floresceu nessa Capitania o Colégio dos Padres Osório ${ }^{10}$, o qual, através das aulas de Latim e de Poética, 
preparava os jovens para os cursos mais graduados.

A respeito dessa instituição de ensino, o próprio Trindade escreveu: “(...) Foi um grande colégio, frequentado por rapazes de toda a capitania (sic) (...) Quando se escrever a história da instrução pública do Estado, estes padres não deverão ser esquecidos (...)." (TRINDADE, 1955, p. 101). E, entre os alunos mais destacados do Colégio dos Padres Osório figura o cônego Francisco Pereira de Santa Apolônia, o qual seria presidente da Junta Governativa da Província de Minas, logo após a Independência do Brasil. Segundo Carrato (1968), Santa Apolônia estudou no referido colégio por volta de 1758 , ou seja, cerca de oito anos após a fundação do Seminário de Nossa Senhora da Boa Morte.

Nos primeiros tempos desse seminário, eram poucos os alunos (aproximadamente vinte), os quais ocupavam cubículos que, mais tarde seriam transformados em quartos. Para se ter uma ideia do edifício do seminário, nos tempos de seu fundador, Pimenta (1920) faz uma descrição de que como era o referido prédio no início do episcopado de D. Antônio Ferreira Viçoso ${ }^{11}$. Apesar do tempo, o seminário era o mesmo, menos a capela ${ }^{12}$, da época do episcopado de D. Frei Manuel da Cruz:

\begin{abstract}
Media de frente, que é sobradada cerca de cento e cinqüenta palmos (aproximadamente trinta e três metros), incluído o vão ou beco de três braças (cerca de um pouco mais de seis metros e meio) (...) que se abre à direita de quem olha para a capela, ficando esta no meio dos dois lanços do edifício a poente e levante. Das duas extremidades desta frente corriam para o sul outros dois lanços, estendendo-se cada um duzentos e cinquienta palmos (mais ou menos cinquienta e cinco metros) (...) cujas pontas eram ligadas pela contrafrente, que desce de nascente a poente, também cento e cinquienta palmos, como a frente à qual respondia, dando ao edifício a forma de um quadrângulo com as dimensões laterais que ficam declaradas. No meio jazia uma grande área, ou páteo (sic) descoberto onde os seminaristas podiam recrear-se jogando, correndo, ou passeando folgadamente nas horas de descanso dos trabalhos intelectuais. A parte da casa à direita da igreja era reservada para as aulas; a da esquerda com os lanços dos lados eram repartidos em quartos ou cubículos, cada um dos quais acomodava três ou quatro alunos, abrindo suas janelas para o páteo ( $\mathrm{sic}$ ), e as portas para um corredor que os perpassava todos, e cercava toda a casa ao redor, muros na frente. Na parte reversa deste quadrângulo se entroncava, no meio, outro lanço do edifício, estendendo-se contra o sul, como se fosse o cabo dele, onde (...) é o refeitório, cozinha e despensa (...).(PIMENTA, 1920, p.156)
\end{abstract}

No Seminário de Nossa Senhora da Boa Morte, os alunos eram preparados para a carreira sacerdotal e também podiam fazer seus preparatórios, inclusive para a Universidade de Coimbra: assim que esse seminário abriu suas portas “(...) tornou-se mais fácil às famílias mineiras, opulentadas pela abundância do ouro que tiravam de suas lavras, seus filhos mais futurosos à Coimbra, para se formarem doutores (...)." (CARRATO, 1968, p.179)

Daí nota-se a existência de certo vínculo entre o estabelecimento fundado pelo primeiro bispo e as classes abastadas, as quais desejavam transformar os proprietários rurais em homens instruídos. Nesse quadro, D. Frei Manuel da Cruz já poderia suprir a carência de estudos públicos em Minas Gerais, procurando satisfazer seus habitantes; e principalmente iniciar o recrutamento de seu clero, que até então inexistia, atendendo ao papa Bento XIV.

No que diz respeito ao clero, no momento da fundação do Seminário de Mariana, as ordens regulares ainda estavam sob a proibição, pelo Estado português, de se fixarem em Minas. O clero secular, por sua vez, se caracterizava pela pouca virtude e, essa situação parece não ter mudado mesmo após a instalação do bispado de Mariana e a fundação do Seminário de Nossa Senhora da Boa Morte, pois os sacerdotes eram formados sem sensibilidade pela cultura de seu próprio povo. Esse mesmo clero: “(...) perdeu a dimensão missionária. Sua função era a de rezar missas nos domingos e dias de festas; e confessar na Páscoa (...).”(HOORNAERT, 1992, p.99)

Não obstante a ausência de ordens religiosas e da presença de um clero nada exemplar, a religiosidade era uma das principais características da população das Minas, no decorrer do século XVIII. Tratava-se, como se viu no primeiro capítulo deste trabalho, de um religiosismo 
decorrente dos primeiros aventureiros que foram tentar a sorte na região mineradora. Esses aventureiros eram marcados pelo sentimentalismo, pelo medo das penas eternas e pelos cultos exteriores, como as romarias e procissões.

Nesse sentido, em benefício do seminário, D. Frei Manuel da Cruz, pôde contar, com as esmolas e doações desse povo religioso, devoto, a exemplo de José de Torres Quintanilha, que possuía lavras nas freguesias de São Caetano e do Furquim, no território onde se criou a freguesia de Barra Longa. E, encorajado por esse começo tão promissor, o bispo não mediu esforços, pois aplicou para o seminário as multas de dispensas matrimoniais e comprou ao Cônego Francisco Ribeiro da Silva a chácara da Intendência ${ }^{13:}$

D. Frei Manuel da Cruz (...) Primeiro Bispo de Mariana (...) Fazemos saber que tendo Nós pelas nossas Bulas Pontificias obrigação de fundar nesta Cidade (Mariana) um Seminário, e tendo para este efeito Licença de Sua Majestade, passada a 12 de setembro de 1748, vendo juntamente a grande necessidade que se há de Seminário nessa Diocese, para nele se ensinar Gramática, Filosofia ${ }^{14}$ e Teologia Moral pois não há neste Bispado estudos públicos, cuja falta causa grande detrimento aos moradores, nós resolvemos a fundar um Seminário e, de fato o erigimos e fundamos com a invocação de Nossa Senhora da Boa Morte, nas casas ${ }^{15}$ que compraram ao Rvdo. Cônego Francisco Ribeiro da Silva (...) (com) o produto das Esmolas dos Fiéis Cristãos (...) fazendo e constituindo Patrimônio do dito Seminário na chácara da Olaria ${ }^{16}$, com sete moradas de casas, de que fez doação ${ }^{17}$ para um Seminário nesta Cidade o devoto José de Torres Quintanilha , com todas as cláusulas e condições declaradas na Escritura de Doação; e gozará o tal Seminário de todas as Isenções e Privilégios, que por Direito lhe são concedidos (...). ${ }^{18}$

Apesar do auxílio dos fiéis o primeiro bispo de Mariana, não deixava de apelar para a Coroa portuguesa, solicitando-lhe esmolas para seu seminário. Por exemplo, em 1753, enviou a D. José I, então rei de Portugal, um relatório sobre a situação do estabelecimento que fundara:

(...) tem o Seminário uma chácara com suas casas (...) Mais duas moradas de casas (...) Por outra chácara mais com oito moradas de casas (...). Todo (o) dinheiro (que o Seminário possui) procedeu de esmolas e juntamente de doações (...) com o fim de haver nele Estudos públicos (...) como este Seminário se funda com esmolas, peço também uma a V. Maj. (...) e, sobretudo peço para esta fundação a Real Proteção de V. Majestade (....). ${ }^{19}$

Se a petição foi ou não atendida, Trindade não informa, mas valendo-se de sua referência a essa atitude do prelado como: “(...) uma grande ingenuidade (...),” (TRINDADE, 1953, p.378), a impressão que causa é a de que não se podia contar muito com a boa vontade do Estado português, quando se tratava de contribuições financeiras para o seminário. De acordo com Freitas (1979), o monarca, na condição de grão mestre, demonstrava pouca generosidade no desempenho de prover às necessidades da Igreja.

No princípio do ano de 1764, quando da morte de D. Frei Manuel da Cruz, os rendimentos da instituição que criara e que eram provenientes de suas chácaras e casas, já incluíam os aluguéis do Palácio Episcopal, então propriedade daquele estabelecimento ${ }^{20}$. E, conforme o plano do primeiro bispo, o padre Francisco Xavier da Rua, governador do bispado, por procuração, e reitor do Seminário de Mariana, em 1772, comprou uma fazenda, situada na freguesia de Paulo Moreira, atual Alvinópolis.

No que diz respeito ao empenho de D. Frei Manuel da Cruz em prover a sua instituição de ensino, torna-se oportuno recordar que, conforme o decreto tridentino, a aplicação dos rendimentos das igrejas no seminário, para o sustento dos alunos provenientes das camadas menos favorecidas, ficava sob o cuidado dos bispos.

\section{Admissão dos alunos no Seminário de Mariana}

Foi visto que o Concílio de Trento estabeleceu algumas condições para a admissão nos 
seminários, tais como: a idade mínima de doze anos; ser filho legítimo; saber ler e escrever; e ser oriundo da mesma diocese a qual pertence o seminário. Conforme Freitas (1979), a primeira condição era expressamente exigida no Seminário do Pará; o qual também exigia a segunda, assim como o Seminário de São José, no Rio de Janeiro; a terceira era explicitamente requerida no Seminário do Pará; e a quarta condição certamente não era exigida de maneira explícita em seminário algum, pelo menos no Brasil.

Daí e pela consulta aos Estatutos e aos Regulamentos do Seminário de Nossa Senhora da Boa Morte, que abrangem o recorte temporal adotado neste trabalho (respectivamente 1760; 1821; e 1845) nenhuma das condições eram explicitamente exigidas. E, no que diz respeito à última condição, esse seminário, recebeu alunos vindos de outro bispado, como por exemplo, Francisco Inácio Marcondes Homem de Mello ${ }^{21}$, oriundo do interior de São Paulo.

Segundo Freitas (1979), a admissão dos alunos nos seminários estava subordinada aos bispos. Nesse compasso, podemos tomar por exemplos: os registros de matrícula do Seminário, de $1792^{22}$, pelos quais se verifica que os alunos foram admitidos por despacho de D. Domingos da Encarnação Pontével, então bispo de Mariana; e os Estatutos de 1821, conforme os quais: “(...) Nenhum será admitido antes do despacho do Exmo. Prelado, em cujo requerimento ajuntarão (sic) a atestação dos seus respectivos párocos de vida, costumes e possibilidades". ${ }^{23}$

Os alunos que saíam dessa instituição por iniciativa própria, poderiam (pelo menos, entre o final do século XVIII e o início do seguinte) ser readmitidos: "Francisco Pinto saiu (...) a três de (?) de 1790 (...) tornou a entrar (...) em 1791 (...)". ${ }^{24}$ Outro exemplo é o de José de Araújo Cunha, o qual “(...) entrou (...) a cinco de abril de 1802. Saiu a (?) de junho de 1803. Tornou a entrar a (?) de outubro de 1803. Saiu de novo a sete de março de 1804 e tornou a entrar no mesmo ano (...)". ${ }^{25}$

Também não eram admitidos somente aqueles que se destinassem ao estado eclesiástico, embora, de acordo com o Concílio de Trento, a palavra "seminário" significasse colégio diocesano que objetivava a formação do clero secular.

A admissão de candidatos que não intentavam o sacerdócio não deixa de estar relacionada à necessidade, por parte do Seminário de Nossa Senhora da Boa Morte, de acolher aqueles cujas pensões contribuiriam com essa instituição, que geralmente tinha dificuldade de sustentar seus alunos pobres.

\section{A preferência pelos alunos pobres}

Como foi mencionado, o decreto tridentino prescreve que os alunos dos seminários devem ser principalmente pobres, apesar de que os ricos não estejam excluídos, desde que se sustentem e manifestem vocação em servir a Deus e à Igreja Católica. No caso do Seminário de Nossa Senhora da Boa Morte, ao mesmo tempo em que se buscava acatar as determinações tridentinas, pesava a necessidade de se prover a instituição, a qual geralmente contava com as esmolas dos fiéis e com uma módica contribuição do governo. Daí existiam nesse seminário, os recebidos a titulo paupertatis e os pensionistas.

Sob a justificativa de sustentar o estabelecimento, eram admitidos aqueles estudantes que podiam contribuir com suas pensões, mesmo aqueles que, conforme Camelo (1986), não almejavam o estado eclesiástico. Então, as contribuições desses alunos eram bem vindas. Por exemplo, nos Estatutos de 1821 do Seminário de Nossa Senhora da Boa Morte, aprovados pelo então bispo de Mariana, D. Frei José da Santíssima Trindade ${ }^{26}$, consta que:

(...) É da intenção da Igreja que estas pias instituições (os seminários) atendam mais os pobres que aos poderosos: porém a razão pede, que não podendo este seminário sustentar somente aqueles, ou ainda a parte mais miserável, por falta de créditos suficientes, admita-se aos que possam concorrer com suas pensões, para com elas se beneficiarem os mais. Pelo que serão recebidos neste seminário sete pretendentes (?) além dos (...) pensionistas, titulo paupertatis, e no número dos mesmos pensionistas poderão ainda ser admitidos aqueles que não intentem o estado eclesiástico (...). ${ }^{27}$ 
Esse bispo, ao assumir o governo da diocese, encontrou o seminário em estado de decadência, e relatou: "Apliquei minha primeira e diligente atenção ao seminário dos ordinandos, querendo-o tão prestante como delineado pelo sacrossanto Concílio de Trento". ${ }^{28}$ Nessa direção, D. Frei José empenhou-se em reparar o edifício e dar novos impulsos à fazenda, a qual voltou a prosperar. E, talvez por causa desta, de acordo com Trindade (1900) eram sustentados no seminário, no início da década de trinta, cerca de dez a doze alunos pobres.

Através das consultas dos registros de matrícula e de documentos que se referem às situações financeiras dos alunos do Seminário de Mariana, constatou-se que em diversas épocas, o número dos recebidos a titulo paupertatis foi inferior ao dos pensionistas. Em 1794, entre trinta e nove alunos, apenas três eram pobres, pois exerciam ofícios, como os de sacristão e de refeitoreiro $^{29}$. Em 1806, de duzentos alunos, cinquenta e três pertenciam às camadas menos favorecidas, dos quais vinte e quatro eram sustentados pelo governo ${ }^{30}$. Em 1827, mais da metade do total dos alunos do Seminário era pensionista ${ }^{31}$. E, em 1835, o número de seminaristas era de vinte e oito, quatro dos quais a titulo paupertatis. ${ }^{32}$

O fato dos alunos pobres constituírem geralmente a minoria no Seminário de Nossa Senhora da Boa Morte, contrariava a decisão conciliar de que deviam ser admitidos, de preferência, aqueles que se originavam da camada mais baixa da sociedade. E, a distância entre essa instituição e os preceitos tridentinos aumentava, ao se verificar que, além de acolher meninos abastados, estes ainda representavam a maioria.

Tanto na época colonial quanto no período monárquico, as rendas dos seminários brasileiros eram, de modo geral, escassas e, como o número dos seminaristas recebidos a titulo paupertatis dependia da condição financeira desses estabelecimentos, essa desproporção entre o número dos alunos pobres e dos pensionistas não foi exclusiva do Seminário de Mariana. ${ }^{33}$

\title{
6. Atuação dos jesuítas no Seminário de Mariana
}

O esforço do primeiro bispo não se restringiu à busca de ajuda financeira para a instituição que havia fundado: em uma carta destinada ao padre José Moreira, confessor de D. José I, então rei de Portugal, D. Frei Manuel da Cruz solicita o envio de padres jesuítas para ministrarem aulas de Teologia e Filosofia no seminário: “(...) que ando fundando para a (...) Companhia (...)." ${ }^{34 .}$ Daí pode-se notar a intenção, por parte do primeiro bispo, de entregar a direção daquele estabelecimento de ensino aos membros da Companhia de Jesus:

\begin{abstract}
(...) $\mathrm{Na}$ frota do ano passado de mil, setecentos e cinqüenta, escrevi ao Rvmo. Padre Carboni, que Deus haja, remetendo-lhe inclusa uma representação que fiz a El Rei, pedindo-lhe que fosse servido mandar-me três Padres da Companhia, para serem Mestres de Filosofia e Teologia neste Seminário (...) e como não vieram nesta Frota de cinqüenta, e um, como eu esperava e me dizem, que a sobredita representação se acha nas mãos de V. Rma., lhe rogo faça a diligência possível para que na Frota próxima futura venham infalivelmente os três Padres, ou Ordem Real, para que se mandem desta Província, pois já neste ano se deve principiar o curso de Filosofia, e não se principiou por falta de Mestres. Também esperava nesta Frota pelo Muito Reverendo Padre Missionário Gabriel Malagrida, como tínhamos ajustado no Maranhão, desculpando-se o impediram várias ocupações e embaraços que tinha (...). ${ }^{35}$
\end{abstract}

Observa-se então que, como foi visto, o Concílio de Trento conferia autonomia ao bispo, deixando que este indicasse o governo e os professores do seminário. Assim, D. Frei Manuel da Cruz escolheu os jesuítas para desempenharem tais funções, como mais tarde, D. Antônio Ferreira Viçoso entregaria a administração do estabelecimento fundado pelo primeiro bispo, aos padres da Congregação da Missão. ${ }^{36}$

Diante da impossibilidade da vinda do padre Malagrida à Mariana, D. Frei Manuel da Cruz voltou suas atenções para o Padre José Nogueira, professor de Humanidades no Rio de 
Janeiro, e seu sobrinho, por via paterna: “(...) e mais lhe quero por ser filho da Companhia (...) Peço (...) a V. Rvma. (...) confirmar a eleição em mestre de Filosofia ${ }^{37}$ desse sacerdote que já, há quinze dias reside, comigo neste palácio e cuja diuturna assistência me é necessária (...)”.38

O Padre José Nogueira chegou a Mariana em 1749, e se tornou o primeiro reitor do Seminário de Nossa Senhora da Boa Morte, onde lecionou Teologia Moral e Latim. Entretanto, o referido padre não teve provisão e nem a administração temporal desse estabelecimento, que coube ao cônego Vicente Jorge de Almeida e ao padre Lino Lopes de Matos (ecônomos). Ao sobrinho do primeiro bispo caberia a direção dos estudos e o zelo pela disciplina.

De acordo com Leite (2000), em 1752, o Padre José Nogueira ainda estava sozinho e era, ao mesmo tempo, professor e missionário: no seminário ensinava piedade e letras aos alunos; na cidade pregava na igreja e confessava. A partir dessa afirmativa, pode-se verificar então que os jesuítas solicitados pelo bispo não haviam chegado à nova diocese .

Em 1753, após o parecer favorável da Câmara de Mariana, emitido em sessão de 24 de outubro desse mesmo ano, D. José I ordenou que fossem para o Seminário de Mariana, os jesuítas solicitados pelo primeiro bispo. Mas, mesmo assim, um pouco mais tarde, em uma carta $^{39}$ enviada ao monarca, sobre as finanças do Seminário, D. Frei Manuel da Cruz aproveita para reforçar o pedido, solicitando a vinda, para a instituição que fundara, de:

\begin{abstract}
(...) cinco Mestres e um Irmão leigo (...) Os P.P. podem e devem vir com a cláusula de que em nenhum tempo poderá vir mais algum sem licença de V. Mag., exceto quando algum dos seis morrer, ou for mudado, porque desta sorte ficam sempre em seu vigor as Ordens de V. Mag. que proíbem residir Religiosos neste Bispado sem licença de V. Mag. (...) não devem entender nas presentes circunstâncias, nas quais, e pelas razões acima expostas o não virem os P.P. considero matéria grave de escrúpulo pelos gravíssimos prejuízos que resultam a estes Povos e a esta Diocese, que se não pode fundar sem sujeitos de letras e virtudes, o que se aprende nos seminários e muito principalmente neste Bispado em que não há outros estudos públicos (...). ${ }^{40}$
\end{abstract}

Contudo, aproximadamente três anos após o consentimento da Câmara de Mariana e a referida ordem do monarca, D. Frei Manuel da Cruz ainda esperava os padres da Companhia de Jesus, pois em uma carta ao padre Malagrida, datada de 1756, o prelado escreveu:

(...) Não é esta ocasião desconveniente para falar V.P. Às Suas Majestades (sic) na
licença que tenho pedido para virem os P.P. para este Seminário, ponderando-lhe o
gravíssimo escrúpulo que há na negação desta licença; porque não me posso capacitar
que deva prevalecer uma razão meramente política (?) (sic), que facilmente se pode
remediar, a uma gravíssima necessidade do pasto espiritual neste Bispado que não pode
ter remédio algum, senão este Seminário e vinda dos P.P. para o administrarem, assim
nas letras, como nas virtudes; pois não há neste bispado (sic) convento algum donde se
costumam valer os Prelados, escolhendo deles os sujeitos mais exemplares para os
ajudarem nos seus ministérios pastorais, reforma da vida e costumes das suas dioceses
(...). ${ }^{41}$

Segundo Trindade (1953), nada consta, no arquivo do copiador de D. Frei Manuel da Cruz, a vinda desses padres, mas certamente vieram, pois, de acordo com Leite (2000), a Companhia de Jesus estabeleceu uma residência na sede do governo eclesiástico em Minas ${ }^{42}$, e da qual foi superior o Padre Manuel Tavares.

Essa mesma residência teve vida efêmera, aproximadamente de um ano, ou um pouco mais, porque segundo Trindade (1953), ela teria sido estabelecida no final de 1756 ou no início de 1757 e, em meados de 1758 o governo expediria a ordem de enviar os jesuítas residentes em Mariana para o Rio de Janeiro.

A sólida cultura humanística da pedagogia jesuítica foi recebida pelos candidatos ao sacerdócio, no Seminário de Mariana, em aulas como as de Teologia Moral e Latim, ministradas pelo Padre José Nogueira; e as de Filosofia, do Padre Manuel Tavares. Os inacianos atuaram, como professores e na direção do Seminário de Nossa Senhora da Boa Morte, com a permissão 
do Estado português. E este, personificado por Sebastião José de Carvalho e Melo, Marquês de Pombal, poderoso ministro de D. José I, deu início a uma intensa perseguição aos jesuítas, a qual viria frustrar os projetos de D. Frei Manuel da Cruz.

No início de 1757, conforme Leite (2000) denunciaram à Corte que D. Frei Manuel da Cruz favoreceu os jesuítas na formação de uma residência em Mariana. Mas os inacianos se estabeleceram na diocese com a permissão da própria Corte portuguesa. Nesse ínterim, José Nogueira $^{43}$ é substituído por Manuel Tavares, na reitoria do Seminário de Mariana. Em 1758, o governo português determinou a expulsão dos jesuítas de Mariana e das aldeias:

(...) Excmo. Rvmo. Sr. (...) Sendo presente a Sua Majestade as freqüentes tentativas de que os Padres da Companhia de Jesus têm feito de anos a esta parte para se estabelecerem nas terras do sul desta Capitania com o aparente pretexto da conversão dos índios; sendo outro sim (sic) informado o mesmo Sr. que os ditos padres com manifesta transgressão das Leis Divinas e Humanas têm abusado do ministério Apostólico, fazendo as mais escandalosas violências aos índios nas aldeias que administram (...) foi servido ordenar aos Governadores das respectivas Capitanias que não permitissem que algum dos referidos Padres passassem às ditas terras e fizessem imediatamente embarcar para Cidade do Rio de Janeiro a todos os que nelas se achassem, substituindo-os os seus ministérios por sacerdotes do hábito de S. Pedro, não se dando mais entrada a algum deles ou seja português ou castelhano, e seqüestrando-se todas as cartas que quaisquer deles mandarem aos outros. O que S. Maj. me manda participar a V. Excia. para que sendo requerido pelos respectivos Governadores, nomêe (sic) para pároco das Aldeias já estabelecidas e das que houverem de estabelecer, clérigos que concorram os requisitos necessários para serem dignos daquelas ovelhas $(\ldots){ }^{44}$

Em resposta a tal determinação do Estado absolutista português, a qual não deixou de constituir um prenúncio das expulsões dos jesuítas de Portugal e do Brasil, respectivamente, em 1759 e 1760, D. Frei Manuel da Cruz escreveu:

(...) Recebi as cartas de V. Excia. (...) e executei as ordens de S. Maj. Ao padre da Companhia $^{45}$ que estava lendo Filosofia no Seminário e, acabando o primeiro ano de Lógica, despedi, e não tive pequena dificuldade em achar clérigo que continuasse com o curso de Filosofia. Neste bispado não admiti regulares, senão os que me apresentavam licença de S. Maj. ou dos Governadores, ou permissão deles, aos quais dava licença para o uso de suas Ordens, que é o que me pertence; porque as Ordens Reais, a respeito da admissão e expulsão dos regulares nesta Capitania são dirigidas aos Governadores dela, como consta das mesmas Ordens, cuja cópia me mandou o mesmo Governador atual. Neste Bispado não há por ora aldeias de índios; mas, se houver no meu tempo, fico prontíssimo para executar as ordens de S. Maj. na forma delas, como sou obrigado, e para satisfazer a esta minha obrigação basta qualquer insinuação do mesmo Sr. (...). ${ }^{46}$

Embora contrariado no seu desejo de que o seminário que fundara continuasse a ser dirigido pelos jesuítas, D. Frei Manuel da Cruz, no contexto do absolutismo e do regime do padroado não hesitou em acatar as ordens reais. Daí é oportuna a afirmativa de que o primeiro bispo de Mariana, assim como os demais, na época colonial, consistiram em instrumentos das determinações da Metrópole. Destarte: “(...) esse sentido de impotência não lhes foi estranho (...)."(BOSCHI, 1986, p.94)

Para desilusão do prelado, as perseguições movidas por Pombal, contra os padres da Companhia de Jesus, chegam ao ápice com a expulsão destes, de Portugal e do Brasil, onde os colégios jesuítas foram fechados. E, ao longo da década de 60 do século XVIII, os jesuítas são perseguidos na França, na Espanha, em Nápoles e em Parma. Nesse compasso, diante da pressão dos governantes católicos europeus, principalmente de Pombal, Clemente XIV suprime, em 1773, a Companhia de Jesus, que seria restaurada, em 1814, por Pio VII.

A expulsão dos jesuítas de Portugal pode ser compreendida pela crescente influência dos jansenistas portugueses sobre a administração pombalina, no que diz respeito à feroz oposição aos jesuítas e à reforma do sistema educacional: “(...) o jansenismo tornou-se uma poderosa força 
religiosa e política, tanto em Portugal como no Brasil.” (VIEIRA, 1980, p.29)

Em 1760, no quadro da expulsão dos jesuítas do Brasil, D. Frei Manuel da Cruz, prescreveu os Estatutos do estabelecimento que fundara (os quais vigoraram até 1821). Conforme Leite (2000) esses Estatutos foram inspirados nos Regulamentos da Companhia. Daí é possível refletir que, nesse caso, a Ordem Régia de expulsão não apagou a influência dos jesuítas, os quais durante um pouco mais de dois séculos tiveram preponderância sobre a instrução e a formação sacerdotal no Brasil Colônia.

\section{Os cursos do Seminário de Mariana: de D. Frei Manuel da Cruz a D. Antônio Ferreira Viçoso}

Segundo Freitas (1979), nos seminários episcopais do Brasil, na época colonial, o professorado era organizado pelos bispos, conforme as circunstâncias e de acordo com os programas de estudos. E o corpo docente desses estabelecimentos compunha-se frequentemente, de sacerdotes pertencentes ao clero secular, como no caso do Seminário de Nossa Senhora da Boa Morte, entre a segunda metade do século XVIII e a primeira metade do século XIX. Inicialmente, seus professores, como foi visto, foram os jesuítas, que foram substituídos, a partir do final da década de 50 dos setecentos, pelos padres diocesanos. Estes ministrariam, por aproximadamente um século, os cursos do referido seminário, não obstante alguns regulares terem, por algum tempo, exercido ali a docência.

No que se refere aos cursos, segundo um trecho da Provisão de Fundação do Seminário de Nossa Senhora da Boa Morte, transcrito no segundo capítulo deste trabalho, seriam ministrados nesse estabelecimento de ensino e de formação sacerdotal, os seguintes cursos: Gramática, Filosofia e Teologia Moral. Todavia, nos primeiros oito anos da supracitada instituição, somente funcionaram os cursos de Gramática e de Teologia Moral, ministrados pelo Padre José Nogueira, membro da Companhia de Jesus, e que permaneceu, por todo esse período, como o único professor do Seminário de Nossa Senhora da Boa Morte. Com a vinda de outro jesuíta, teve início o curso de Filosofia.

Considerando que a direção dos estudos do Seminário de Mariana ficou, por cerca de oito anos, sob a cargo de um jesuíta, acredita-se que, nessa época, os cursos ministrados na supracitada instituição tenham tido por base o Ratio Studiorum, o já mencionado Plano de Estudos da Companhia de Jesus, que organizava o ensino nos colégios jesuítas da Europa e do Brasil Colônia. Mas, no cenário das perseguições, por parte da administração pombalina, aos jesuítas, o já mencionado Alvará régio, de 28 de junho de 1759 extinguiu todos os estabelecimentos de ensino regulados pelo método dos inacianos:

(...) Tendo consideração outrossim a que, sendo o estudo das Letras Humanas a base de todas as Ciências, se vê nestes Reinos extraordinariamente decaído daquele auge, em que se achavam quando as Aulas se confiaram aos Religiosos Jesuítas; em razão de que estes com o escuro, e fastidioso Método, que introduziram nas Escolas destes Reinos, e seus Domínios; e muito mais com a inflexível tenacidade, com que sempre procuraram sustentá-lo contra a evidência das sólidas verdades, que lhe descobriram os defeitos, e os prejuízos do uso de um Método, que, depois de serem por ele conduzidos os Estudantes pelo longo espaço de oito, nove, e mais anos, se achavam no fim deles tão ilaqueados (sic) nas miudezas da Gramática, como destituídos das verdadeiras noções das Línguas Latina, e Grega, para nelas falarem, e escreverem sem um tão extraordinário desperdício de tempo, com a mesma facilidade, e pureza, que se tem feito familiares a todas as outras Nações da Europa, que aboliram aquele pernicioso Método; dando assim os mesmos Religiosos causa necessária à quase total decadência das referidas duas Línguas (...). ${ }^{47}$

Além de proibir a utilização do método dos padres da Companhia de Jesus, o supracitado Alvará reformou os estudos de Latim, Grego e Retórica. O Alvará recomenda aos professores de Gramática Latina utilizarem o novo método, do padre Antônio Pereira, da Congregação do 
Oratório, ou a Gramática reformada, do professor Antônio Félix Mendes. Nessa direção, ficou proibido, para o ensino da supracitada disciplina, o uso do livro do padre jesuíta Manuel Alvarez, assim como os comentários e explicações de seus comentadores. De modo geral, por intermédio do referido Alvará, o governo português pretendia uma reforma das Letras Humanas, por meio da restituição do: “(...) Método antigo, reduzido aos termos simplices (sic), claros, e de maior facilidade, que se pratica atualmente pelas Nações polidas da Europa (...).,48

Nesse quadro, foram empreendidas as primeiras providências para a execução das reformas previstas no Alvará de 1759. Em Portugal e em seus domínios ultramarinos realizaramse concursos para a escolha dos professores régios. Porém: “(...) a supressão dos colégios jesuítas não se efetuou sem que sérios transtornos comovessem o 'sistema' de instrução colonial." (CARVALHO, 2003, p.98)

Mas, após a administração e direção dos estudos menores terem sido transferidas para a Real Mesa Censória ${ }^{49}$, as dificuldades foram atenuadas. Conforme Carvalho (2003), esta instituição organizou um mapa com a discriminação das cidades, dos tipos de aula e do número de professores indispensáveis. No entanto, tal plano exigiu a instituição de um fundo financeiro para a manutenção dos estudos reformados. Nessa direção, foi estabelecido, em 1772, um imposto especial, o subsídio literário que: “(...) deveria garantir aos professores régios ordenados que lhe permitissem 'decente honestidade de habitação e de independência'. (CARVALHO, 2003, p.99)

Embora os recursos do subsídio literário nem sempre tenham sido aplicados na manutenção das aulas e tenha havido insuficiência de professores: “(...) a reforma dos estudos menores, com desigual e variável alcance, de uma para outra região, lentamente se implantou (...)." (CARVALHO, 2003, p.100) Nesse compasso, Carvalho (2003) se refere ao Colégio e Seminário de Olinda, onde:

(...) sacerdotes seculares, oratorianos e outros regulares ensinavam, de acordo com as diretrizes da Universidade de Coimbra, reformada em 1772, teologia dogmática e teologia moral, história eclesiástica, filosofia, matemática, ao lado dos estudos de retórica e poética, grego, latim, cantochão, primeiras letras e desenho (...). (CARVALHO, 2003, p.100)

O Colégio e Seminário de Olinda, fundado, em 1800, pelo Bispo D. José Joaquim da Cunha de Azeredo Coutinho, teve uma proposta pedagógica que refletiu uma visão burguesa de mundo, no que diz respeito ao domínio do homem sobre a natureza, por intermédio da ciência moderna.

Assim, no supracitado estabelecimento, o ensino de Gramática Latina, prático e útil, tinha por base a língua nacional, diferente do manual jesuítico do Padre Álvarez; a Retórica procurava superar a aspiração jesuítica de formação do orador sacro, buscando formar o diplomata: “(...) a serviço do capitalismo em que a busca de novos mercados se revelava uma questão crucial para a burguesia européia (...);" (ALVES, 2003, p.70), o curso de Filosofia se diferenciava daquele ministrado nos colégios jesuítas, no tocante à sensível preponderância das ciências modernas dentro do estudo filosófico e o curso de Teologia, o qual tinha a duração de três anos e possuía, de acordo com Alves (2003), indicadores que ressaltavam seu caráter regalista: no primeiro ano do referido curso, estudava-se História Eclesiástica, sob responsabilidade do padre José Miguel Reinau, filiado ao galicanismo ${ }^{50}$; no segundo ano, a Teologia Especulativa: “(...) feria a ortodoxia católica quando desenvolvimento da doutrina dos 'lugares teológicos', invertia dois escalões (...) dos 'lugares derivativos secundários': a autoridade papal caía para plano inferior em relação ao 'consenso dos bispos' (...);" (ALVES, 2003, p.71). No último ano, a Teologia Moral antagonizava-se com a orientação jesuítica. ${ }^{51}$

Não obstante as diferenças, o Seminário de Olinda se assemelhava aos colégios jesuítas, no que tange ao seu caráter duplo: formava tanto quadros da Igreja Católica, quanto jovens das elites que se preparavam para estudos superiores na Metrópole. 
No quadro das aulas régias, expressões das reformas pombalinas e, do florescimento do Colégio e Seminário de Olinda, no crepúsculo do período colonial, a educação no Brasil, se distanciava cada vez mais, do método pedagógico dos padres da Companhia de Jesus.

Nos Estatutos do Seminário de Nossa Senhora da Boa Morte, de 1760, não obstante ter manifestado sua estima pela Companhia de Jesus ${ }^{52}$, D. Frei Manuel da Cruz adotou, como observa Carrato (1968) as reformas previstas pelo Alvará de 1759, pois, o Estatuto $3^{\circ}$ prescreve que: "Às oito horas irão às classes, onde se observará (...) as instruções para os professores (...) e mandadas publicar por El Rei (...) para uso das escolas (...) em seus reinos e domínios (...)."

Conforme tal Alvará e outras Providências literárias, de 1772, foram criadas, em Mariana, as escolas públicas das primeiras letras, Gramática Latina e Portuguesa, Retórica e Filosofia Racional e Moral. E, segundo uma Representação da Câmara de Mariana, de 1816, que se refere a um projeto de um Colégio de Artes e Disciplinas no edifício do Seminário de Nossa Senhora da Boa Morte, as aulas, foram ali fechadas: “(...) talvez por concorrência dos Estudos Régios de Gramática e Filosofia (...).",54

Provavelmente tais Estudos Régios tenham contribuído para o fechamento do Seminário de Mariana, mas outros fatores, que serão abordados mais adiante, provocaram a decadência da instituição fundada por D. Frei Manuel da Cruz, tais como: a má situação financeira e da falta de alunos, no cenário do relaxamento das ordenações e também a abertura, por D. Frei Cipriano, então bispo de Mariana, de um curso noturno de Teologia Moral, em sua própria residência. Mas, em 1821, o Seminário de Mariana foi reaberto por D. Frei José da Santíssima Trindade, com os seguintes cursos: Gramática Latina, Retórica, Filosofia, Teologia Moral e Teologia Dogmática.

No período monárquico, todos os seminários brasileiros foram divididos, conforme Freitas (1979), em: menor (onde os alunos fariam seus cursos preparatórios) e maior (destinados àqueles que pretendem seguir a carreira sacerdotal). Nesse contexto, o Seminário de Mariana foi dividido, em 1845, por D. Antônio Ferreira Viçoso, então bispo de Mariana, em: Colégio Episcopal, reservado ao curso de Humanidades, e Seminário, onde aqueles que desejavam o estado eclesiástico faziam o curso teológico.

No período compreendido entre a direção, por parte dos padres da Companhia de Jesus, dos estudos do Seminário de Nossa Senhora da Boa Morte, até a época do episcopado de D. Frei José da Santíssima Trindade, o curso de Gramática, na instituição de D. Frei Manuel da Cruz, é referido também como Latim.

Na Provisão de Fundação do Seminário de Mariana, como foi visto, o curso em questão consta como Gramática. Nas cartas de D. Frei Manuel da Cruz, ora é mencionado curso de Gramática, ora de Latim. Em um documento, datado de 1752, o Padre José Nogueira, refere-se a si mesmo como: “(...) mestre de Latim (...)".

Por um lado, considerando-se o caráter clássico, humanístico, da formação no Seminário de Mariana, pode-se afirmar que o Latim tinha preponderância no curso de Gramática. Por outro, levando-se em conta o fato de que tal curso era ministrado por um jesuíta, vale recordar que, os padres da Companhia de Jesus não negligenciavam o idioma pátrio. Daí não é impossível acreditar que a Gramática beneficiasse, em maior ou menor grau, a formação do aluno no conhecimento da língua materna.

Mas, em sua abordagem a respeito do mencionado seminário, entre o final do século XVIII e as primeiras décadas do século XIX, Trindade se refere aos docentes do curso de Gramática como professores de Latim. A partir dos Estatutos de 1821, no contexto do episcopado de D. Frei José da Santíssima Trindade, tal curso passa a se denominar Gramática Latina, e seus mestres, como os sacerdotes Miguel Arcanjo da Encarnação e Egídio da Cunha Osório continuam a ser mencionados como: “(...) professores de Latim.” (TRINDADE, 1953, p.400)

Nessa época, os supracitados Estatutos estabeleciam que, haveria no Seminário de Nossa Senhora da Boa Morte, lição diária de Gramática Latina, por duas vezes: “(...) das oito horas até 
às dez da manhã e das três às cinco da tarde (...)" ${ }^{56}$ Os exames de Latim eram realizados no final do ano letivo, na presença do reitor e dos professores do Seminário. E, a estas aulas: “(...) Serão admitidos (...) todos aqueles que não estiverem capazes de perceber, com facilidade, os autores clássicos (...)." ${ }^{, 57}$

Embora não sejam mencionados os nomes de tais autores, certamente não eram aqueles desaprovados pelo Concílio de Trento, e talvez os mesmos estudados nos colégios jesuítas, tais como Cícero e Ovídio. Conforme Hansen (2001), tal Concílio, insistindo na oposição de beatitude e libertinagem, considerava imorais os cômicos Plauto e Terêncio, autores ligados a um gênero considerado baixo.

Em uma de suas sessões, o Concílio de Trento, condenou a tese, segundo a qual Lutero prescreve que o fiel deve se colocar em contato com Deus, por intermédio da leitura solitária da Bíblia, não precisando, assim, da mediação do clero e dos cerimoniais da Igreja Católica. E, como foi visto no segundo capítulo desta dissertação, Lutero traduziu a Bíblia para o alemão, procurando transformá-la em um livro popular.

Daí em oposição à tese luterana, o referido conclave considerou que apenas os sacerdotes, como sucessores dos apóstolos de Cristo, poderiam explicar o texto sagrado. Nesse compasso, a Vulgata, ou seja, a tradução da Bíblia em Latim, feita por São Jerônimo, foi declarada, pelo Concílio de Trento, a versão oficial da Igreja Católica. Isto contrariava a tentativa de Lutero de tornar a Bíblia diretamente acessível ao povo e reafirmava a obrigatoriedade do conhecimento do Latim pelos sacerdotes: “(...) Os fiéis devem ler as Escrituras nas edições acompanhadas de explicação aprovada pela Igreja. Destarte, afirmava-se o espírito comunitário católico contra o individualismo protestante." (MOUSNIER, 1957, p.100)

Assim, tanto nos colégios jesuítas, quanto nos seminários, a exemplo do estabelecimento fundado por D. Frei Manuel da Cruz, o estudo do Latim era parte integrante da formação de sacerdotes e de letrados ${ }^{58}$. No Seminário de Mariana, de acordo com os Estatutos de 1821, o aluno só seria admitido às aulas de Retórica após ter sido aprovado em Gramática Latina, ou seja, depois de conhecer: “(...) a ciência das palavras, dos termos e das frases de que usam os Autores das Artes e das Ciências (...)".59

O conhecimento da linguagem dos clássicos consistia, então, em um instrumental para a aquisição dos saberes dirigidos pela Igreja e por ela adaptados ao dogma católico, tais como a Retórica, a Filosofia e a Teologia (Moral e Dogmática).

A Retórica não é mencionada na Provisão de Fundação do Seminário de Nossa Senhora da Boa Morte. Porém, na parte em que trata dos reitores do estabelecimento fundado por D. Frei Manuel da Cruz, Trindade (1953) afirma que o Padre Antônio Rodrigues Dantas, antes de assumir a reitoria dessa instituição, em 1768, ali dava aulas de Latim e de Retórica.

Assim como a supracitada Provisão, outros documentos utilizados nesta dissertação, tais como editais e cartas que se referem ao Seminário de Nossa Senhora da Boa Morte, entre a segunda metade do século XVIII e o início do século seguinte, não mencionam o curso de Retórica. Mas, considerando a afirmativa de Trindade, supõe-se que, nesse período, a Retórica fazia parte de algum curso, como por exemplo, de Gramática.

Entretanto, conforme os Estatutos de 1821: “(...) estabelecendo-se presentemente os estudos de Gramática Latina; de Filosofia Natural, Racional e Moral; assim também os de Teologia Dogmática e Moral; quando se não possa acrescentar os de Retórica (...). ${ }^{60}$ Daí tem- se a impressão de que não existia, antes dos supracitados Estatutos, o curso de Retórica no Seminário de Mariana. Contudo, levando-se em conta a formação clássica dos alunos desse estabelecimento, talvez fosse possível que eles tivessem recebido, no século XVIII, pelo menos alguns rudimentos, algumas noções de oratória. Segundo os mesmos Estatutos, a Retórica: “(...) arte de bem falar pois ela é a que bem ordena os pensamentos, a distribuição e o ornato (...)",61 passa a ocupar, no seminário marianense, uma posição de destaque, pois tais Estatutos dedicam um capítulo somente a ela. Mediante essa "arte", o aluno adquire a expressão poderosa e convincente, instrumento necessário aos sacerdotes, em suas pregações, e também aqueles que 
desejam seguir a carreira política, a qual não dispensa a eloquência, a oratória.

De acordo com Hansen (2001), a Retórica assumiu papel fundamental no quadro da referida contestação, por parte do Concílio de Trento, da tese luterana que prescreve a leitura individual da Bíblia. Tal "arte" seria indispensável à pregação oral, como forma de divulgar a fé pela tradição (transmitida por Cristo aos seus apóstolos e aos sacerdotes). Nessa direção, pelos Estatutos de D. Frei José da Santíssima Trindade, a Retórica: “(...) admira a simplicidade dos Evangelhos com a sublimidade da locução e figuras das Escrituras Santas com a grandeza da sabedoria criada (...)." ${ }^{\prime 62}$ Essa relação entre a Retórica e a leitura dos textos sagrados parece destacar a importância da primeira na preparação dos futuros sacerdotes para a pregação dos Evangelhos.

Apesar de que os Estatutos de 1821 não mencionem os autores estudados no curso de Retórica, no Seminário de Mariana, com certeza não se trata daqueles desautorizados pelo Concílio de Trento, e provavelmente os mesmos utilizados nos estabelecimentos de ensino da Companhia de Jesus, tais como: Cícero e Quintiliano.

Esses Estatutos ainda recomendam ao professor de Retórica mandar os alunos fazerem dissertações: “(...) dispondo-as sempre conforme a razão, a Religião e à verdade que condenam o vício e reprovam a licença a que o coração humano é tão propenso (...)". ${ }^{63}$ Daí observa-se que, na linha da pedagogia jesuítica, sob a égide do Concílio de Trento, D. Frei José da Santíssima Trindade coloca a "arte" de bem falar a serviço da Igreja Católica. Esta, combatendo o vício e a licenciosidade, defende a virtude, a moral, os bons costumes, qualidades exigidas nos seminaristas. Não constam nos referidos Estatutos, o horário das aulas de Retórica, eles somente prescrevem que os exames dessa "arte", à semelhança da Gramática Latina, seriam realizados no final do ano letivo.

A respeito do curso de Filosofia, no Seminário de Nossa Senhora da Boa Morte, torna-se oportuno recordar que: apesar dessa instituição contar, desde 1750, com um perito em Filosofia, tal curso só teve início depois de aproximadamente oito anos; e foi marcado pela instabilidade (suspenso em 1769 e reaberto em 1772).

Também é importante lembrar que, no cenário da expulsão dos jesuítas de Mariana, D. Frei Manuel da Cruz informou ao governo português, por meio de uma carta que, havia despedido o professor de Filosofia, no final do primeiro ano de Lógica. Daí verifica-se que, à semelhança do currículo filosófico da Companhia de Jesus, alinhado aos ditames tridentinos, a Ciência, no Seminário de Mariana, também fazia parte da Filosofia (aristotélico-tomista), encontrando-se, desta maneira, vinculada à religião.

No decorrer de grande parte da segunda metade do século XVIII, o curso de Filosofia, na instituição de D. Frei Manuel da Cruz, foi regido pelo Cônego Luís Vieira da Silva: “(...) uma ilustração respeitável para o tempo em que vivia: tinha vasta leitura, sendo possuidor de uma das mais ricas bibliotecas da capitania (...).” (TRINDADE, 1955, p.63)

Apesar de não ter sido homem de grandes recursos financeiros, esse sacerdote que nunca frequentou uma universidade europeia, conseguiu reunir um acervo excepcional: "(...) não tanto pelo número dos volumes coletados, mas pela sua apurada qualidade e atualidade (...)." (CARRATO, 1968, p.112)

O cônego Luís Vieira da Silva cuidava de sua cultura sacerdotal, por meio do conhecimento de Teologia Dogmática (São Tomás de Aquino) e de Patrística (Santo Agostinho, São Gregório Magno, São Bernardo, São Jerônimo, entre outros autores). E, como o currículo filosófico, nesse contexto, abrangia as ciências, o cônego Luís Vieira da Silva não poderia dispensar os livros sobre: Geometria, Matemática, Física e Astronomia.

Porém, na biblioteca do supracitado cônego podiam-se encontrar obras dos mais obstinados inimigos da Igreja, como Voltaire ${ }^{64}$, e de propagandistas do espírito revolucionário da época, a exemplo de Raynal ${ }^{65}$. No entanto, não cabe a este trabalho abordar a existência de obras consideradas libertinas, na biblioteca do cônego Vieira, além do mais: “(...) A posse de certos livros (...) nem sempre é critério suficiente para identificar com as do autor as idéias do 
possuidor." (LUZ, 2003, p.449)

No início do século XIX, o curso de Filosofia, no Seminário de Nossa Senhora da Boa Morte, continuaria a serviço da religião católica, pois, de acordo com os Estatutos de D. Frei José da Santíssima Trindade, de 1821, a Filosofia constituiria:

(...) uma ciência necessária a qualquer estudante, para entrar na percepção de todas as mais (...) e (...) deste estudo se espera grande utilidade aos que frequentarem pela qual se pode preparar um clero capaz de edificar a Igreja (...). ${ }^{66}$

Todavia, entre o final do século XVIII e o começo do seguinte, o mundo passara por uma transformação radical:

(...) As idéias e as instituições passavam por uma crise agudíssima. A Revolução tinhase (sic) erguido contra o passado. O Espírito das Leis, e o Contrato Social e outros livros desse gênero veiculavam pelo mundo as suas teorias triunfantes (...). (TRINDADE, 1953, p. 191)

Nesse quadro, influenciado por tais ideias e pelo ambiente de liberalismo que se instalara nas Minas, o padre Antônio José Ribeiro Bhering ${ }^{67}$, professor de Filosofia do Seminário de Mariana, pregava, em suas aulas, novidades filosóficas que: “(...) nada se acomodavam com os dogmas e com a disciplina da Igreja (...)." (TRINDADE, 1953, p. 193). E, apesar de advertido, o supracitado professor insistiu em pregar sua doutrina "subversiva" no interior da austera instituição de D. Frei Manuel da Cruz. Deste modo, Bhering foi exonerado do quadro docente, por D. Frei José da Santíssima Trindade, gerando a já comentada perseguição política a este bispo.

Conforme os Estatutos de 1821, as aulas de Filosofia eram ministradas, no Seminário de Mariana, duas vezes ao dia (pela manhã, entre oito e nove e meia e à tarde, entre três e quatro e meia). E, os alunos tinham que fazer argumentos e dissertações acerca do assunto estudado. Na época do episcopado de D. Viçoso, no quadro da divisão do referido estabelecimento de D. Frei Manuel da Cruz, o curso de Filosofia passou a ser ministrado no Seminário Menor.

De acordo com a referida Provisão de Fundação do Seminário de Nossa Senhora da Boa Morte, o curso teológico, nesse estabelecimento, restringiu-se à Teologia Moral. Mas, conforme um Edital do Cabido, datado do início do período de Sede vacante que se seguiu à morte de D. Frei Manuel da Cruz, e que foi transcrito pelo próprio Trindade, lê-se: “(...) findo que seja o (...) curso de Filosofia, se dê princípio no (...) Seminário ao da Teologia, assim Especulativa como Moral (...)".68

Porém, esse curso de Teologia Especulativa ou Dogmática não foi ministrado, nessa época, no Seminário de Mariana, pois, conforme os Estatutos de 1821, a partir dessa data, D. Frei José da Santíssima Trindade criou o curso de Teologia Dogmática, que: “(...) pertence ao dogma e à defesa da religião (....." ${ }^{69}$ Tais Estatutos conservaram o curso de Teologia Moral, também denominada Teologia Prática: “(...) que não se pode dispensar ao ministério do sacerdócio, e da direção das almas."70

A instalação do curso de Teologia Dogmática no Seminário de Nossa Senhora da Boa Morte pode ser compreendida pelo empenho, por parte de D. Frei José da Santíssima Trindade, em restaurar o prestígio desse estabelecimento, que vinha passando por um período de declínio, inclusive moral, como foi visto no capítulo anterior. Tal curso, dedicado à defesa dos dogmas católicos e, assim alinhado aos preceitos tridentinos, não deixaria de elevar a imagem da instituição de D. Frei Manuel da Cruz como digna representante dos interesses da Igreja Católica. Nesse compasso, de acordo com os Estatutos elaborados por D. Frei José da Santíssima Trindade:

Chegamos ao ponto mais essencial da salvação das almas, que a Sagrada Teologia ensina, e nas verdades reveladas, que a revelação impugna, querendo a moldar a Lei de Deus, as disposições da Santa Madre Igreja, e a sujeição que a natureza, a razão e os preceitos divinos ordenam aos soberanos da Terra, ao modo de pensar da Filosofia, 
infecta e as inclinações da paixão de cada um (...). ${ }^{71}$

Pode-se verificar, então que, D. Frei José da Santíssima Trindade a opõe a Teologia à maneira de pensar da Filosofia infecta, a qual, conforme Oliveira (1998) constitui possível referência às novas correntes filosóficas iluministas e laicas, em voga na época em que tais Estatutos passaram a vigorar.

Nesses mesmos Estatutos, D. Frei José da Santíssima Trindade não deixa de revelar uma preocupação com a formação de sacerdotes, voltando suas atenções para a Teologia Moral: “(...) matéria vasta e muito extensa que obriga todo eclesiástico estudá-la sempre, e nunca se persuadir que a tem compreendido (...)." ${ }^{, 72} \mathrm{E}$ acrescenta que: “(...) nenhum estudante poderá chegar ao sacerdócio sem aprovação do seu lente e atestação da sua conduta, inclinação ao Santo ministério e do aproveitamento nos seus estudos (...)." ${ }^{, 73}$ As aulas de Teologia Moral, nessa época, eram ministradas uma hora e meia por dia, no Seminário de Mariana. E, todos os dias, os estudantes tinham a oportunidade de: “(...) oferecer suas dúvidas, as quais se decidirão para que melhor fiquem na memória dos que estudam (...).",74

A partir de 1845, no cenário da divisão, feita por D. Antônio Ferreira Viçoso, do Seminário de Nossa Senhora da Boa Morte, o curso teológico passou a ser ministrado na seção que posteriormente seria denominada Seminário Maior, exclusivo aos candidatos destinados à carreira sacerdotal.

\section{A formação sacerdotal}

No que diz respeito à formação sacerdotal o decreto tridentino não fixou taxativamente o que se deveria ensinar. Apenas enumerou as matérias mais necessárias à formação do clero, como: a explicação das Sagradas Escrituras; os Livros Eclesiásticos; as Homílias dos Santos, enfim: “(...) tudo o que se requer para a boa administração dos sacramentos, principalmente da confissão, ritos e cerimônias sagradas.” (FREITAS, 1979, p.36)

Quanto à formação do clero no Brasil Colônia, especificamente, as Constituições do Arcebispado da Bahia, Código da Igreja no Brasil a partir de $1707^{75}$, não se referem aos seminários, restringindo-se às descrições das ordens menores e ordens sacras; e as condições para a admissão em cada um de seus graus.

Conforme tais Constituições, as ordens menores dividiam-se em: ostiário, leitor, exorcista e acólito, enquanto as sacras integram: subdiácono, diácono e presbítero ou sacerdote. Porém, para não se estender em abordagens que não seriam interessantes a este trabalho, serão abordados apenas os graus das ordens sacras, que são assim chamadas, por que "(...) aqueles que as recebem ficam mais dedicados e consagrados a Deus assim pelo voto, que fazem de castidade, como pela impossibilidade de poderem tomar outro estado secular (...)." (VIDE, 1710, p.91)

Mas, antes de tratar dos três graus das ordens sacras, torna-se oportuno se referir à primeira tonsura, a qual, não significa propriamente uma ordem, mas uma disposição para as ordens. Daí se formam os clérigos, que ficam dedicados à Igreja. Para tal disposição, é necessária a idade de sete anos completos; o conhecimento da doutrina cristã; e ler e escrever.

Para o subdiaconato, exige-se que o candidato seja examinado da doutrina cristã e mistérios da fé; além do conhecimento: de Latim “(...) construindo algum capítulo do Concílio Tridentino, ou de outro livro Latino, uma Epístola, ou Evangelho, ou uma lição do Breviário (...)" (VIDE, 1710, p.92); dos sacramentos; das censuras eclesiásticas; matérias morais; breviário para rezar horas canônicas; e canto.

O diácono ou ministro propriamente dito tem por ofícios: ler publicamente o Evangelho na igreja; administrar ao sacerdote nos sacrifícios; e pregar ao povo a palavra divina. O candidato ao diaconato deve ser examinado no Latim; casos de consciência; reza; e canto; e ter passado um ano como subdiácono.

Por fim, o sacerdote é responsável pela administração dos santos sacramentos; instrução 
dos fiéis nos mistérios da fé; e tudo que seja necessário para a salvação. Assim, o candidato ao sacerdócio deve ter vida e costumes exemplares, e será examinado rigorosamente em: Latim; moral; reza; e canto. Ainda se lhe perguntará acerca do sacrifício da Missa, por suas partes e mistérios. Depois de recebida a ordem para se lhe dar licença de dizer Missa nova, será examinado de Cerimônias. E, será recebido a esta ordem depois de passado um ano no diaconato.

Esses exames de ordens eram feitos diante de três examinadores, escolhidos diretamente pelo arcebispo: “(...) pessoas de autoridade, letras, experiência, e inteireza (...) para eles chamaremos ao Provisor, Vigário Geral e Desembargadores, e outras pessoas doutas, e Religiosas, que nos parecer (...).”(VIDE, 1710, p.96)

Nos seminários brasileiros, tanto na época colonial, quanto no período monárquico, a formação em piedade (devoção, religiosidade) buscava atender aos preceitos tridentinos. Os seminaristas recitavam em comum as preces matinais, da noite, e o terço; faziam meia hora de oração mental, um quarto de hora de leituras espirituais; assistiam todos os dias à missa; e deviam se confessar e comungar uma vez por mês.

Não se encontrou informações detalhadas a respeito da formação de sacerdotes no Seminário de Nossa Senhora da Boa Morte. Sabe-se, por um relatório ${ }^{76}$ de D. Frei Manuel da Cruz que, em 1757, antes da abertura do curso de Filosofia, tanto os alunos internos (provavelmente os que se destinam ao estado eclesiástico) quanto os externos ${ }^{77}$, cursavam, por oito anos, Gramática e Teologia Moral.

No final do século XVIII, os candidatos ao sacerdócio estudavam Gramática, Filosofia e Teologia Moral no Seminário de Mariana. E, pela consulta dos registros de matrículas referentes ao período supracitado ${ }^{78}$ deduz-se que, esses candidatos também faziam, na referida instituição, exames para as ordens. Daí cita-se alguns exemplos: Antônio Carlos Machado entrou em 1790 e saiu ordenado presbítero em 1792; Antônio José de Castro ingressou em 1792 e saiu como subdiácono em 1793; Antônio Luís Coelho, clerigo in minoribus, entrou em 1794, e saiu em 1795, para todas as Ordens.

Nos dois primeiros casos, não se sabe em que grau ou ordem os candidatos se encontravam, no momento de suas respectivas matrículas. Mas, no último caso, nota-se que, em um período de aproximadamente um ano, o candidato passou, das ordens menores para todas as ordens, ficando entendido que o mesmo tenha atingido o sacerdócio. Deste modo, este candidato se tornou presbítero em um tempo menor do que nos outros dois casos.

Ainda nos dois primeiros casos, não se tem informações a respeito da formação dos candidatos. No terceiro caso, observa-se que o candidato possuía, pelo menos, os conhecimentos necessários para as ordens menores. Porém, pode-se afirmar que o tempo previsto nas Constituições do Arcebispado da Bahia, para as ordens, não era, na prática, seguido à risca.

Nesse compasso, pode-se destacar o caso de Belchior Pinheiro de Oliveira, cujo registro de matrícula no Seminário de Mariana data de fevereiro de 1798. Segundo Guimarães (1972), Belchior permaneceu nessa instituição até julho do mesmo ano e, no dia seis de outubro ele recebeu a primeira tonsura e as ordens menores; no dia seguinte, tornou-se subdiácono; uma semana depois, em Itapetininga, bispado de São Paulo, foi promovido a diácono; e finalmente, em dezembro, foi feito presbítero, no Oratório do Palácio Episcopal de São Paulo.

De acordo com Guimarães (1972), Belchior fez seus estudos preliminares na instituição fundada pelo primeiro bispo de Mariana. No entanto, torna-se difícil compreender o fato de que Belchior tenha realizado tais estudos apenas em alguns meses. Contudo, há de se considerar que, no final dos setecentos, foram numerosas as ordenações, sem a exigência do currículo seminarístico, e essas prosseguiram mesmo no período em que o Seminário de Mariana esteve fechado, entre 1811 e 1820 . Mas, esse assunto será abordado mais adiante.

Em 1821, D. Frei José da Santíssima Trindade, então bispo de Mariana, após ter reaberto o Seminário de Nossa Senhora da Boa Morte, elaborou os novos Estatutos dessa instituição, e destaca no que se refere ao sacerdócio, a importância dos seguintes cursos: Filosofia, de 
Teologia Moral e de Teologia Dogmática. E, segundo Trindade (1953, p.191), no tempo do referido prelado, o período entre a primeira tonsura e o sacerdócio, era de sete a nove anos.

Provavelmente, tais cursos não perdem sua importância, no episcopado de D. Antônio Ferreira Viçoso, pois este bispo se preocupou muito com a formação dos sacerdotes, e dividiu o seminário, destinando uma parte deste somente aos alunos que desejavam seguir a carreira sacerdotal. Tal divisão será detalhadamente abordada em outro tópico. E, devido à mencionada preocupação deste bispo, o tempo entre a primeira tonsura e o presbiteriato, deveria ser tão rigoroso quanto o da época de D. Frei José da Santíssima Trindade.

Além desses cursos, a formação em piedade, no Seminário de Nossa Senhora da Boa Morte, era reforçada, por meio das aulas de Cerimônias, Catecismo e Canto-chão, ou seja, canto litúrgico da Igreja Católica, monódico (a uma só voz, sem acompanhamento, também denominado Canto Gregoriano ou Liso).

\section{O Seminário de Mariana em Sede vacante de D. Frei Manuel da Cruz}

Em 1747, antes da chegada do primeiro bispo à nova diocese, o então rei de Portugal, D. João V, sob o Grão-Mestrado da Ordem de Cristo, erigiu o Cabido ${ }^{79}$ da Catedral de Mariana, executando as prescrições do Moto Proprio Candor lucis aeternae, do papa Bento XIV. E, apesar do absolutismo e do padroado, o monarca português concedeu a D. Frei Manuel da Cruz a faculdade de “(...) nomear as Dignidades e Cônegos da mesma Catedral, e instituir logo os que por vós forem nomeados, sem embargo de não estarem confirmadas por mim as nomeações $(\ldots)$ ".. 80

No ano seguinte, instalado o Cabido, o primeiro bispo tinha esperança de que essa corporação o assistisse na administração espiritual e material da diocese de Mariana. Porém, esse mesmo Cabido, em momento algum esteve à altura de sua responsabilidade, e sim constituindo: “(...) um capitulo de mesquinharias e quizílias ( sic), que jamais se acabaram, em toda a história colonial de Minas Gerais (...).” (CARRATO, 1968, p. 58). E, segundo Trindade (1953), D. Frei Manuel da Cruz, no momento da criação do Cabido, não poderia imaginar que aqueles sacerdotes seriam responsáveis pelas contrariedades que mais amargaram o seu governo.

Entretanto, com a morte do prelado, tem início o período denominado Sede vacante, ou seja, que se estende entre o falecimento do bispo titular até a eleição de seu sucessor. A partir daí o governo da diocese de Mariana passou para o Cabido, tendo à frente a figura do vigáriocapitular.

Logo que assumiu o bispado de Mariana, o Cabido redigiu um Edital sobre o Seminário de Nossa Senhora da Boa Morte e, um trecho desse documento lembra o já referido caráter humanístico da educação jesuítica, na direção ao preparo de homens para assumirem uma posição de liderança: “(...) da ciência das letras depende o maior aumento pelo qual se fazem os homens distintos e recomendáveis para a promoção dos empregos mais relevantes da República $(\ldots)^{81}$.

Nesse tempo, o seminário era dirigido por um padre diocesano, Teodoro Ferreira Jácome, indicado pelo próprio D. Frei Manuel da Cruz, no final de 1763, estando este já enfermo. Conforme Trindade (1953), não obstante o Cabido ter nomeado outro sacerdote, Francisco Gomes de Sousa, para a direção daquele estabelecimento, Jácome, mediante um recurso à Coroa portuguesa, permaneceu na administração temporal até sua morte, em 1766.

Embora colocado nessa posição pelo Cabido, cuja reputação não era das melhores, o cônego Sousa fez bom governo, pois, houve aumento no número de alunos, e o patrimônio deixado por D. Frei Manuel da Cruz permaneceu intacto. Manteve-se na reitoria até 1767, quando foi sucedido por outro eclesiástico: Francisco Xavier da Silva.

Este, por sua vez, teve como sucessor o padre Antônio Rodrigues Dantas, o qual, em 1768, passa a administrar aquela instituição até 1769 , ano em que é substituído pelo padre Manuel Alves Trigo. Nesse mesmo ano, de acordo com Trindade (1953) foi suspenso o curso de 
Filosofia. O motivo que levou ao fechamento dessa cadeira não foi esclarecido por Trindade. Segundo Coelho (1994), o curso de Filosofia não se conservava no Seminário de Mariana, por falta de rendas.

Porém, não se sabe exatamente se esta foi a causa da suspensão, pois segundo Trindade (1953), no período de Sede vacante, o seminário encontrava-se em boas condições financeiras, e o curso de Filosofia prosseguia animadoramente. Assim, seria necessária uma acurada investigação antes de afirmar que essa cadeira tenha sido suspensa naquele ano, por falta de rendas.

Ainda a respeito desta administração, no capítulo em que trata estritamente do Seminário de Nossa Senhora da Boa Morte, Trindade (1953) se refere à suspensão do curso de Filosofia, o qual seria reaberto em 1772, logo após o término do período de Sede vacante, pelo padre Francisco Xavier da Rua, governador do bispado e ao mesmo tempo reitor do seminário. Contudo, não faz referência alguma a respeito de que esse estabelecimento foi fechado nessa época.

Mas, na parte em que se refere aos reitores do Seminário de Mariana, Trindade (1953) informa que essa instituição esteve fechada, entre as administrações do padre Trigo e a do governador Rua ${ }^{82}$ e não menciona a causa desse fechamento. Problemas financeiros provavelmente não foram, pois Trindade (1953) havia afirmado que, entre 1764 e 1771, as finanças do estabelecimento eram animadoras; talvez nem falta de alunos, cujo número havia crescido no início dessa fase.

Em 1772, através de uma pastoral, o governo do bispado divulga a reabertura do curso de Filosofia, “(...) que se há de abrir no seminário desta Cidade (Mariana) (...)",83, no mês de agosto desse mesmo ano, mas não sugere, nem faz menção de que aquele estabelecimento estivesse fechado e seria reaberto.

\section{Decadência moral e patrimonial do Seminário de Mariana}

Após um período de sete anos de Sede vacante, foi eleito bispo de Mariana, D. Joaquim Borges de Figueiroa ${ }^{84}$. Como não veio à diocese, tomou posse, em fevereiro de 1772, por seu procurador, o referido padre Francisco Xavier da Rua, o qual permaneceu no governo até 1775, quando administrava a diocese em nome de D. Bartolomeu Manuel Mendes dos Reis ${ }^{85}$ que, assim como seu antecessor não viera a Mariana.

O episcopado de D. Figueiroa foi curto, pois permaneceu na administração da diocese até outubro de 1773, exercendo-a pelo seu supracitado procurador. E, não obstante a curta duração de seu governo, este foi marcado pela atenção que deu ao Seminário de Nossa Senhora da Boa Morte, por meio da já mencionada pastoral, em que divulga a reabertura do curso de Filosofia. Apesar da estabilidade financeira do seminário, que marcou o chamado governo dos procuradores, verifica-se, nessa época, um aspecto que revela o declínio moral pelo qual passavam o seminário e a diocese: o relaxamento das ordenações sacerdotais.

Segundo Coelho (1994), sob a administração de Rua, grande número de indivíduos foram ordenados, sem escolha, inclusive um membro da tropa remunerada do governo da Capitania. Esse relaxamento perdurou nos governos dos procuradores que sucederam Rua: José Justino de Oliveira Gondim, no qual foram ordenados sacerdotes dispensando mulatismos e ilegitimidades, contrariando as exigências de genere $^{86}$. E, Inácio Correia de Sá, seu sucessor ordenou um indivíduo que devia à Fazenda Real.

No entanto, a prática de se ordenar sacerdotes sem o currículo seminarístico se manteve após o fim do governo desses procuradores, e prosseguiu durante o episcopado de D. Frei Cipriano de São José ${ }^{87}$. Inclusive, as ordenações continuaram no tempo em que o Seminário de Nossa Senhora da Boa Morte esteve fechado, entre 1811 e 1820. Nesse quadro, foram conferidas as ordens de presbítero a setenta e dois pretendentes ${ }^{88}$.

Constata-se então que, em nove anos houve um número de ordenações superior à metade 
do total verificado na administração de D. Frei Domingos da Encarnação Pontével (1780-1793): cento e vinte e cinco em onze anos (1782-1793) ${ }^{89}$, época em que o seminário encontrava-se aberto.

Mas, não se pode afirmar com absoluta certeza que todo o clero das Minas, no século XVIII, tenha se preparado no Seminário de Mariana. E, quando este estabelecimento fechou, os candidatos ao sacerdócio certamente estudaram Latim, Retórica e Filosofia Racional e Moral nas escolas públicas; e fizeram a preparação teológica com vigários em suas paróquias.

De acordo com Carrato (1968), na época de D. Frei Manuel da Cruz, graças à rígida linha de disciplina e às normas, o Seminário de Mariana formou sacerdotes dignos de sua missão religiosa e social. Boa parte dos padres saídos desse estabelecimento, ao longo do governo do primeiro bispo, destacou-se pelos seus dotes intelectuais de bons pregadores e por suas qualidades ministeriais de pastores de almas ${ }^{90}$. Porém, chegariam os tempos de estagnação moral daquele seminário, do qual sairia uma “(...) frouxa geração de padres, a quem os viajantes ${ }^{91}$ (...) torcem o nariz, por causa de seu geral desinteresse sacerdotal, exceção feita de alguns idosos, saídos do Seminário marianense (...).” (CARRATO, 1968, p.59)

Quanto à situação financeira do Seminário de Nossa Senhora da Boa Morte, o período que se estende da morte de D. Frei Manuel da Cruz, até o fim do episcopado de D. Frei Domingos da Encarnação Pontével, foi de prosperidade para o Seminário de Mariana: seu patrimônio estava acrescido de uma fazenda, cujos rendimentos nessa época eram animadores; e o estabelecimento podia contar com as contribuições financeiras do referido bispo. Além disso, o Palácio Episcopal, propriedade do seminário, foi aumentado e melhorado.

Porém, em 1793, com a morte de D. Pontével, tem início outro período de Sede Vacante, no qual a diocese de Mariana estaria novamente sob o governo do Cabido, cuja má administração foi responsável pela fase de decadência na qual entraria o Seminário de Mariana. De acordo com Trindade (1953), por essa época, tal estabelecimento mal possuía recursos financeiros para pagar o reitor e os professores.

Em 1798, ao chegar à Mariana, o novo bispo, D. Frei Cipriano de São José herdara do Cabido um seminário decadente, o qual constituiu sua grande preocupação, pelo menos no início de seu episcopado. Tal preocupação pode ser observada por meio de um Edital, datado de 1800, através do qual o referido bispo convida os jovens para o estabelecimento fundado por D. Frei Manuel da Cruz:

(...) entre os muito e conhecidos deveres do Ministério a que nos trouxe a Divina Providência tem sem dúvida o primeiro lugar o cuidado de boa educação da mocidade, a fim de que se possa prover de virtuosos e sábios Ministros à Igreja, à República de bons e fiéis cidadãos; e sendo esta Diocese tão dilatada e a mais estéril de casas religiosas, onde, com as ciências, se possa beber a boa morigeração; pelo presente Edital damos a saber a todos os diocesanos, nossos súditos, que projetamos dar as necessárias providências para tão justo fim, provendo de Estudos e Mestres o Seminário Episcopal de Mariana, e porque não tem aquela casa outro fundo que não seja a pensão dos porcionistas já estabelecida e taxada, procuramos, por este convite, que os pais dos que intentarem a admissão de seus filhos, a Nós recorram em qualquer parte onde nos acharmos nesta digressão e visita para calcularmos e resolvermos a reparação do Seminário e assistência dos Seminaristas e Porcionistas. Para que chegue a todos o presente aviso mandarmos ao Rdo. Vigário-Geral do Sabará o possa publicar em toda a sua comarca e freguesia de Pitangui e ainda pelas capelas $(. ..) .^{92}$

De acordo com Trindade (1953), o convite foi renovado por D. Frei Cipriano por mais duas vezes. Porém, não obstante seu interesse inicial, este bispo, aos poucos iria abandonando o seminário, o qual ainda teria alunos até 1811 , ano em que foi fechado. E, a partir dessa data, até 1817, ali permaneceria, em companhia de três escravos, apenas o reitor, padre Manuel Ribeiro da Cruz, o qual pregava e dirigia os exercícios espirituais aos ordinandos.

Conforme Carvalho (1981), os seminários episcopais do Brasil Colônia, de modo geral, sob os cuidados dos padres da Companhia de Jesus, foram fechados temporária ou 
permanentemente, logo após a expulsão da referida Ordem. Tal assertiva causa a impressão de que, com a saída dos jesuítas os seminários brasileiros, entraram imediatamente em decadência. Entretanto, no caso do Seminário de Nossa Senhora da Boa Morte, foi visto que, mesmo no tempo em que ali atuava um jesuíta, o padre José Nogueira, tal instituição já passava por dificuldades, tais como: a carência de maiores recursos financeiros e um número insuficiente de professores.

Entre 1758 e 1780, ou seja, no período que abrange a saída dos inacianos de Mariana e o exercício do episcopado marianense pelos chamados procuradores, não obstante a estabilidade financeira verifica-se uma decadência moral do Seminário de Mariana, no que diz respeito ao afrouxamento das ordenações sacerdotais. Nesse compasso, conforme Carrato (1968), tal decadência se relaciona ao fato de que, no referido período dos procuradores não havia, à frente da diocese de Mariana, um pastor cheio de força administrativa, virtude e zelo apostólico. Considerando tal afirmação, observa-se que, o declínio moral do Seminário de Nossa Senhora da Boa Morte deve-se à incúria dos eclesiásticos que assumiram o governo episcopal na fase de Sede vacante de D. Frei Manuel da Cruz, e não propriamente à expulsão dos jesuítas.

Apesar de ser inegável a contribuição dos inacianos, no que tange aos cursos e às primeiras normas do Seminário de Mariana (Estatutos de 1760), torna-se importante recordar que a atuação de D. Frei Manuel da Cruz foi fundamental para a manutenção do supracitado estabelecimento de ensino e de formação sacerdotal. Daí acredita-se que devido aos esforços desse bispo, o qual praticamente formou o patrimônio da instituição que fundara; e à sua autoridade moral e zelo administrativo, o Seminário de Mariana não entrou em decadência patrimonial, nem moral, no momento da saída dos jesuítas.

\section{O Seminário fechado}

Diante da má situação financeira e da falta de alunos, no quadro do relaxamento das ordenações, o seminário que já vinha perdendo o brilho que possuía nos tempos de seu fundador, acaba fechando. E, nesse cenário, assim como "(...) os príncipes ilustrados europeus fundaram e mantiveram suas próprias academias (...).” (CARRATO, 1968, p.70) D. Frei Cipriano abriu, em seu próprio palácio, um curso noturno de Teologia Moral. Assim, como observa Trindade (1953), parece que o próprio bispo estaria colaborando para que o seminário permanecesse fechado.

Alguns anos mais tarde, o sucessor de D. Frei Cipriano de São José, o já mencionado D. Frei José da Santíssima Trindade colocaria em questão as causas do abandono daquele estabelecimento: “(...) desguarnecido e como que abandonado! Ignoro se por alguma falta de recursos ou por incúria de seus administradores. Os prédios (...) em ruínas, dissipado o patrimônio e (...) sem alunos e sem funcionamento (...)". ${ }^{93}$

Passando por Mariana, na segunda década do século XIX, o viajante e botânico francês Saint-Hilaire (1975) escreveu que o patrimônio da instituição, a exemplo de suas terras e escravos, estava decadente; e os mineradores, cuja riqueza diminuíra, não poderiam se sacrificar pelo estabelecimento; e, ao invés de uma união entre as autoridades civis e eclesiásticas, objetivando amparar o seminário, julgou-se mais cômodo fechá-lo. No tempo em que esteve naquela diocese, Saint-Hilaire (1975) observou que: “(...) Os morros dos arredores de Mariana são estéreis e incultos (...) Hoje em dia não existem em torno de Mariana mais que quatro lavras em exploração; mas a gente pobre vai procurar no leito dos córregos (...)." (SAINT-HILAIRE, 1975, p.80) Tais efeitos não deixariam de atingir a instituição criada por D. Frei Manuel da Cruz, assim como a sede do bispado como um todo.

Em 1816, ainda no episcopado de D. Cipriano e, estando fechado o seminário, a Câmara de Mariana fez uma proposta de reabertura, à revelia do bispo, apresentando ao monarca português, D. João VI, o projeto de estabelecimento, no edifício do mesmo seminário, de um Colégio de Artes e Disciplinas Eclesiásticas. Essa petição foi informada por D. Manuel de 
Portugal e Castro, governador da Capitania de Minas. A petição da Câmara, porém, não surtiu efeito e o seminário continuou fechado até 1820, ano da posse de D. Frei José da Santíssima Trindade, como bispo de Mariana, o qual logo no início se lança à tarefa de tirar aquele estabelecimento da situação de decadência em que se encontrava.

\section{Reabertura do Seminário}

Quando D. Frei José da Santíssima Trindade assumiu a diocese de Mariana, o edifício do seminário necessitava de reparos e sua fazenda: “(...) com dezoito escravos muito velhos (...) apenas rendia para seu custeio e doze moradias de casas sem fundamento e sustentadas em taipas (....)"94. Então, o bispo lançou-se à tarefa de reerguer o seminário, começando a aplicar suas próprias economias e pedindo esmolas por seus párocos ${ }^{95}$. Assim, logo o bispo ordenou a reparação de todo o edifício e deu novos impulsos à fazenda: de estéril passou a florescer rapidamente e produzir com abundância tal que “(...) sustentava, só ela, o Seminário e o Paço (...).” (TRINDADE, 1953, p.186) À semelhança de D. Frei Manuel da Cruz, o qual recorria à Coroa portuguesa, em busca de ajuda para o estabelecimento que criara, D. Frei José da Santíssima Trindade também solicitou auxílio do governo português em favor dessa instituição que encontrara praticamente em total abandono:

(...) lembrando-me do Banco ${ }^{96}$ estabelecido por Sua Maj. nessa Corte do Rio de Janeiro, poderia ficar fixa esta aplicação, em tendo nele algumas ações para de seu rendimento se sustentarem os empregados do mesmo seminário. Por isso, humildemente recorro à inata piedade, zelo e religião do nosso augusto soberano, que se digne mandar se me recebam por agora quatro ações que tenho prontas e que aplico para este fim. ${ }^{97}$

Todavia, segundo Trindade (1929), nenhum vestígio se encontra da transação das apólices bancárias. Verifica-se então que, como o primeiro bispo, D. Frei José também não podia depender da vontade do Estado português para reerguer a mencionada instituição, embora recebesse uma módica contribuição anual de D. Pedro I, conforme havia pedido em 1820. Mas, mesmo assim, no início de 1821 , o prelado reabriu o estabelecimento, “ (...) dotando-o de mestres idôneos $(\ldots)^{\text {"' }}$. 98

Conforme Oliveira (1998), a reabertura do seminário constituiu uma mudança profunda de suas estruturas materiais, como por exemplo, a reforma de seu edifício e da promoção de sua fazenda. Mas, a importância da ação de D. Frei José foi mais extensa, pois reformou os Estatutos aprovados pelo primeiro bispo. Essa reforma será detalhadamente abordada quando se tratar da vida interna no Seminário de Mariana.

Porém, é oportuna a transcrição de um trecho da introdução dos Estatutos de D. Frei José da Santíssima Trindade, o qual, provavelmente com o objetivo de recuperar o prestígio da instituição fundada pelo primeiro bispo, refere-se à utilidade dos seminários, ou colégios diocesanos, e à sua recomendação pelo Concílio de Trento:

\footnotetext{
De quanta utilidade seja para a boa ordem moral e civil, os seminários públicos, basta chamarmos a juízo a própria experiência, para sem muito trabalho fazermos justiça a estabelecimentos tão (?) e necessários. Foi por este motivo, que os Padres do Concílio de Trento, e os Sagrados Pontífices, nas suas Bulas Apostólicas, recomendam aos (...) Bispos estas pias instituições, querendo, em cada um dos Bispados não se admitam estudantes ao estado eclesiástico, sem que primeiro se instruam, e preparem nestas casas de educação (...). ${ }^{99}$
}

Depois daquela fase de declínio moral expressa pelo relaxamento das ordenações, D. Frei José, em suas visitas pastorais, procurava inculcar a prática das virtudes sacerdotais e a obrigação do estudo das matérias eclesiásticas, negando as provisões ao sacerdote que não assistisse às conferências teológicas, prescritas em toda a diocese. $\mathrm{O}$ prelado: “(...) Não era fácil em conferir ordens (...).” (TRINDADE, 1953, p.191) 


\section{O Seminário no limiar do período monárquico}

No episcopado de D. Frei José, o Brasil tornou-se independente de Portugal, através do célebre grito de D. Pedro, às margens do rio Ipiranga, no dia sete de setembro de 1822. Mas, sabe-se que a emancipação do Brasil não foi realizada abruptamente naquele local. Nossa independência resultou de um processo que teve início com a transferência da Família Real portuguesa para a sua colônia na América, diante da invasão das tropas napoleônicas em Portugal. Daí uma série de medidas foram conferindo uma gradual autonomia econômica e política ao Brasil, a abertura dos portos brasileiros às nações amigas (1808); e a elevação da Colônia à condição de Reino Unido de Portugal e Algarves (1815).

Tal processo se acelerou no cenário da tentativa, por parte das Cortes portuguesas, instaladas com a vitória da Revolução do Porto (1820), de recolonizar o Brasil. Nesse quadro, as elites brasileiras, interessadas em manter a autonomia até então conquistada, aliaram-se ao príncipe regente D. Pedro, no projeto de fundação de um império, mantendo a unidade territorial do Brasil, ao contrário da América espanhola, que se fragmentara em repúblicas, por intermédio de lutas que contaram com a participação popular. Deste modo, as elites conduziram o processo de emancipação do Brasil, deixando o povo à margem dos acontecimentos.

Apesar da independência, o Brasil não rompe totalmente com seu passado colonial, a exemplo da interferência do poder civil, expresso pelo Grão Mestrado da Ordem de Cristo, nos negócios da Igreja Católica: logo o governo monárquico manifestaria seu desejo de preponderar sobre essa instituição.

E, como foi visto no capítulo anterior, a Constituição de 1824 conservava o padroado e o placet. No quadro da conservação do padroado, a Assembleia Geral Legislativa aprovou em 1827, uma lei que impediu a execução de um documento papal que criava seminários nos novos bispados. Assim, a criação desses estabelecimentos passou para a competência da autoridade civil. Mas, até 1851 não estava firmado o princípio de intervenção no regime interno dessas instituições. A partir dessa data, a aprovação dos professores nomeados pelos bispos e dos compêndios das aulas sujeitam-se ao poder executivo, o qual “(...) se julgou autorizado a esbulhar os Bispos do pleno direito no regimen ( sic) dos colégios diocesanos, e constituir-se legislador destes institutos (...).” (FREITAS, 1979, p.107)

A interferência da autoridade civil, por força da manutenção do padroado no período monárquico, se fez sentir no Seminário de Nossa Senhora da Boa Morte, no início da década de trinta do século XIX. Entretanto, a perseguição movida pelo governo civil, contra esse estabelecimento tinha suas raízes nos anos vinte do referido século.

Antes de se referir ao fato que desencadeou tal perseguição, faz-se necessário abordar a postura de D. Frei José, em relação ao contexto da proclamação da independência do Brasil. Esse bispo, ao jurar, em 1821, a Constituição portuguesa, causara má impressão nos patriotas mineiros. Mas, segundo Trindade (1953), assim que soube do brado de D. Pedro, o prelado apoiou tal gesto, através de uma pastoral patriótica.

Quanto ao acontecimento que gerou a mencionada perseguição: em 1829, D. Frei José excluiu, do quadro docente do seminário, o padre Antônio José Ribeiro Bhering, sob a justificativa de que este professor de Filosofia pregava, em suas aulas, teorias filosóficas que se confrontavam com os dogmas da Igreja Católica. A partir daí o padre Bhering moveu junto ao Conselho Geral da Província, uma campanha contra o supracitado bispo, o qual, devido aquele juramento ainda era suspeito. Nesse cenário, D. Frei José relata, em carta, ao Núncio Apostólico:

(...) comunico (...) a V. Excia. que na reunião do (...) Conselho da Província, em princípio deste Dezembro, começaram já a tratar sobre meu Seminário Episcopal, para chamarem a si a revisão e exame dos Estatutos, que eu lhe dei na sua restauração, a título de inconstitucionalidade, sendo o autor desta indicação um sacerdote que nele se criou, aprendeu e por ele foi sustentado, provido de livros pela sua nímia (sic) pobreza (...) e ao depois serviu de lente de Filosofia por dois anos, até que angariado pela 
demagogia para desmoralizar os alunos e os mais, fui constrangido a lançá-lo para fora, e então se desmascarou em escritos públicos contra mim (...) e contra o mesmo Seminário (...)..$^{100}$

Esse Conselho, então, exigiu, por intermédio de um ofício, que o bispo respondesse às seguintes questões: 1) quanto pagavam antigamente os estudantes que frequentavam as aulas do seminário e que residiam fora dele? 2) quanto pagam atualmente? 3) mediante qual lei ou ordem? 4) por qual motivo foi alterada a prática de frequentarem gratuitamente as aulas do seminário aqueles alunos que nele não residiam? 5) quem instituiu o seminário, que o dotou, e quais foram as condições com que se fez a doação, e se estas foram cumpridas, ou se alteradas, como, quando e por quem? 6) que se remetam cópias autenticadas de todos esses esclarecimentos. Depois de alguns dias, D. Frei José da Santíssima Trindade respondeu nas margens do próprio ofício:

(...) 1) Não sei; 2) $8 \$ 000$ anuais; 3) Pelo Estatuto do mesmo Seminário; 4) Pela Necessidade; 5) O primeiro Bispo da Diocese Dom Frei Manuel da Cruz, e ao mais deste artigo respondam os defuntos; 6) Não tenho rendimentos para satisfazer o prolixo trabalho dos amanuenses (...). (TRINDADE, 1953, pp.401-402)

Contudo, o Seminário, pela lei em vigor, não estava sujeito ao poder provincial e sim ao governo central. De acordo com Freitas (1979) certamente foi este o motivo pelo qual, em 1831, a Assembleia Geral Legislativa renovou aquelas exigências. Por fim, segundo Trindade (1953) os adversários do bispo, fatigados e impotentes, deixaram-no em paz.

Não obstante as reformas realizadas por D. Frei José, o Seminário de Mariana conforme Oliveira (1998) entrou em decadência a partir de 1830. Este autor se refere ao patrimônio desse estabelecimento, com base em um inventário de $1831^{101}$ e em Vasconcelos (1935), como um amontoado de coisas irrisórias, incluindo os bens imóveis, o Palácio Episcopal; a fazenda; os objetos de culto da capela (roubada em 1829); e os escravos (velhos e doentes).

Mesmo em acentuado processo de declínio, o Seminário de Nossa Senhora da Boa Morte continuou funcionando normalmente até 1842, quando sofreu as consequências do movimento revolucionário que se disseminou pelas províncias de São Paulo e de Minas: a Revolução Liberal.

\section{Tempos difíceis}

Com a morte de D. Frei José da Santíssima Trindade, em 1835, tem início o período de Sede vacante, o qual se estenderia até 1844, embora, nesse período, dois homens foram chamados a ocupar o governo da diocese de Mariana. O primeiro seria o padre Diogo Antônio Feijó $^{102}$, em 1835, e que, na condição de regente do Império recusou a nomeação para bispo da referida diocese. O segundo, o sacerdote Carlos Pereira Freire de Moura ${ }^{103}$ chegou a ser confirmado em 1840, mas faleceu no ano seguinte.

Nessa fase de Sede vacante o clero se compunha de sacerdotes, os quais, em sua grande maioria levavam uma vida nada exemplar, à semelhança dos tempos coloniais, inclusive um vigário capitular, o qual: “(...) marcava na Sé lugar honroso à sua amásia (...).” (TRINDADE, 1953, p.221) Desta maneira, o mal exemplo vinha do alto e se verificava em Mariana, cabeça do bispado. Além disso, os clérigos não agiam às ocultas, porque: “ (...) quando não tinham as mulheres em casa, tinham-nas em casa sabida e conhecida, donde lhes vinha a comida e onde passavam as noites $(. ..){ }^{\prime \prime}{ }^{104}$

E, a conduta dos seminaristas, de modo geral, se assemelhava a daqueles sacerdotes, pois nesse período de Sé vaga, o Seminário de Mariana: “(...) estava de tal jeito que os alunos saíam de noite para as casas de amásias que tinham na cidade, apesar da reclusão em que eram guardados, dormindo com as portas fechadas (...)". ${ }^{105}$

No cenário da decadência moral que marcava a diocese e o Seminário de Nossa Senhora 
da Boa Morte, é desencadeado na província de Minas Gerais, o movimento revolucionário que ficaria conhecido como Revolução Liberal de 1842, e cuja causa está relacionada com as disputas entre liberais e conservadores pelo poder. Essa rebelião havia começado em São Paulo, e se estendeu por algumas cidades mineiras, inclusive Mariana.

Em consequência da revolução, o estabelecimento fundado pelo primeiro bispo transformou-se em quartel. E, para Pimenta (1920), é provável que os soldados tenham provocado estragos no edifício do seminário. Em agosto do mesmo ano, essa instituição foi fechada, não obstante, de acordo com Trindade (1953) a aula de Moral continuasse funcionando.

Encontrando-se fechado o Seminário de Mariana e a Sé vaga, os velhos adversários do estabelecimento entenderam que era chegado o momento de arrancá-lo à diocese e aliená-lo em proveito da Província. Entretanto, o cônego Francisco Rodrigues de Paula, sob pseudônimo de Levita, redige um texto (o qual correu em impresso avulso), em favor dos direitos da Igreja e da diocese sobre o Seminário de Nossa Senhora da Boa Morte. E, diante da erudição e eloquência de Levita, a Assembleia Provincial se manifesta favorável ao seminário e ao bispado.

Pouco tempo depois, os revoltosos foram derrotados pelas tropas governamentais, e a paz voltaria a reinar em Minas. Todavia, o movimento rebelde e a má administração do bispado em Sede vacante deixaram o seminário em um estado deplorável, tanto que, ao tomar posse como novo bispo de Mariana, em 1844, D. Antônio Ferreira Viçoso encontrou o prédio necessitado de reparos, com apenas um aluno em seu interior e a fazenda desorganizada.

\title{
15. Divisão do Seminário
}

Diante do referido estado em que encontrou a mencionada instituição, o novo bispo realizou reparos no edifício: ergueu no antigo pátio um sobrado para as salas de aula; e transformou os cubículos em quartos. Quanto à fazenda, esta foi vendida por D. Viçoso, o qual, com o produto da venda, mais as esmolas dos fiéis, organizou o patrimônio do Seminário.

Como D. Frei José da Santíssima Trindade, D. Viçoso franqueou o ingresso no Seminário de Mariana, aos que não desejavam se tornar sacerdotes e, que pudessem auxiliar a instituição com suas pensões. E, diante de um número considerável desses alunos, o bispo resolveu extremá-los dos estudantes do curso teológico:

\begin{abstract}
Aumentando-se notavelmente o número dos alunos do nosso seminário, e destinados uns ao estado eclesiástico, não se podendo outros decidir ainda sobre a escolha do seu estado futuro, pela pouca idade; e até mesmo decidindo-se outros exclusivamente à vida civil, temos julgado conveniente encarregar o cuidado dos eclesiásticos ao Rvdo. (...) Reitor Pe. João Antônio dos Santos (...) restava a outra parte, que não destina ao estado eclesiástico: não saibamos a quem (...) entregar (...). ${ }^{106}$
\end{abstract}

Em 1845, D. Viçoso repartiu o Seminário de Nossa Senhora da Boa Morte em duas seções: o Colégio Episcopal, reservado ao curso de Humanidades; e o seminário propriamente dito, onde os candidatos ao sacerdócio faziam o curso de Teologia. E, embora funcionassem no mesmo prédio, teriam reitores distintos, apesar de que, em 1848, conforme Freitas (1979) as reitorias das duas seções se acumularam na mesma pessoa. Mais tarde, o supracitado Colégio passaria a ser chamado Seminário Menor; e a seção destinada ao curso teológico, seria denominada Seminário Maior.

\section{A entrega do Seminário aos padres da Congregação da Missão}

No século XIX, os padres da Congregação da Missão regiam seminários em vários países da Europa. Nesse mesmo século, esses religiosos se destacaram pela fundação do Colégio do Caraça, em Minas Gerais. Tal estabelecimento de ensino foi criado por aqueles padres, sobre os escombros da Irmandade de Nossa Senhora Mãe dos Homens, fundada na serra do Caraça, na freguesia de Catas Altas, no século XVIII, pelo Irmão Lourenço de Nossa Senhora. 
Este Irmão, de quem se suspeitou ser um nobre que se embrenhara nos sertões de Minas Gerais, fugido da perseguição movida pelo Marquês de Pombal aos acusados de envolvimento em um atentado ${ }^{107}$ a D. José I, então rei de Portugal, adquiriu uma sesmaria de terras na referida serra, onde erigiu um santuário, do qual se fez ermitão. Inicialmente, de acordo com Souza (1998), era apenas uma capela da Irmandade de Nossa Senhora da Mãe dos Homens, com romaria e hospício para peregrinos. Em 1806, mediante testamento, o Irmão Lourenço, faz doação, ao príncipe regente D. João, dos bens da referida irmandade para que ali fosse estabelecido uma escola para meninos e uma residência de missionários:

Declaro que sou possuidor e senhor de uma sesmaria de terras sitas na Serra do Caraça,
com mais terras anexas à mesma, que são notórias a todos e constaram de meus títulos,
onde à minha custa e com esmolas edifiquei uma Capela com o título de Nossa Senhora
Mãe dos Homens (...) com todos seus pertences, ornamentos, alfaias, imagens,
santuário de várias relíquias (...) do que é de todos os demais bens que me pertencem,
fiz oferecimento por mim e pelas Câmaras de Caeté, Cidade de Mariana e Vila Rica a
S.A.R. (Sua Alteza Real) para estabelecimento de um Hospício de Missionários com
coro regular e ainda não sei se S.A.R. foi servido mandar informar-se pelos seus
Ministros. Declaro que a minha vontade sempre foi e é de que todos os referidos bens
fossem para estabelecimento e residência de Missionários na forma do dito meu
oferecimento a S.A.R.; e não podendo conseguir-se para esse fim, que em tal caso
servisse para um Seminário de meninos, onde aprendessem as primeiras letras e mais
artes, ciências e línguas (...).

Mas, o Irmão Lourenço ainda viveria mais treze anos aproximadamente, pois faleceu no dia 27 de outubro de 1819. Daí o terreno de sesmaria, a capela e os seus bens foram doados a D. João VI, com o ônus de ali estabelecer a escola de meninos e a residência de missionários. Em dezembro desse mesmo ano chegaram ao Rio de Janeiro, vindos de Portugal, os padres lazaristas Leandro Rabelo Peixoto e Castro e Antônio Ferreira Viçoso, os quais D. João VI mandara vir, para lhes confiar a missão de catequizar índios no Mato Grosso. No entanto, o monarca havia, a pouco, recebido o testamento do Irmão Lourenço, declarando-o herdeiro do Santuário da Nossa Senhora Mãe dos Homens, na serra do Caraça. Desta forma, tomou nova resolução: entregou a referida missão a um capuchinho, e fez a doação do santuário aos supracitados padres. A partir daí com a permissão do governo, uma ordem religiosa se estabeleceria em Minas, contrariando a orientação anterior, pela qual o Estado português havia proibido a fixação de religiosos regulares na mencionada Capitania:

D. Manuel de Portugal e Castro Governador e Capm. General de Minas Gerais. Amigo, eu El Rei nos envio muito saudar. Houve por bem aceitar a instituição da Igreja, que Lourenço de N. Sra. Mãe dos Homens fez das terras e capela que possuía na serra do Caraça, pelo testamento com que faleceu e foi aberto (...) para a minha Real pessoa, pedindo-me a instituição de um Hospício para Missionários (...) Fui também servido aprovar à mesma disposição testamentária concedendo as dispensas (...) necessárias para tais fundações e determinar que no edifício da Igreja fique esta estabelecida ( sic) um Hospício para os Padres da Congregação da Missão de São Vicente de Paulo, a fim de que estes não somente aquela Igreja administrem palavra e socorros espirituais, mas dali hajam de sair em missões pelos lugares da referida Província de Minas Gerais e pelas outras províncias onde possam acudir, e os ordinários do lugar lho pedirem para este efeito, fiz doação da mesma Casa e Igreja, terras e mais pertences da dita herança à Congregação da Missão e determinou aos padres Leandro Rabelo Peixoto e Castro e Antônio Ferreira Viçoso que fossem dela tomar posse e estabelecer a sua Casa regular na conformidade dos seus Estatutos, e principiar a exercer as missões com a cláusula, porém que devem ali darem hospitalidade a outros quais que (sic) missionários de outra qualquer Ordem Religiosa, que se determina de passagem por essa Província, ou por ordem minha estejam para o mesmo piedoso fim $(\ldots) .^{109}$

Em 1820, os padres chegaram ao santuário e dele tomaram posse, com todas as formalidades jurídicas. Entretanto, nos primeiros tempos, os referidos missionários passaram por 
privações, sendo obrigados a recorrer à caridade pública e à boa vontade de D. Frei José da Santíssima Trindade, para se manter.

No mês de outubro desse mesmo ano, o padre Leandro Peixoto trouxe do Rio de Janeiro as bases do futuro Colégio do Caraça: quatro jovens para serem alunos e três sacerdotes. Tal Colégio, inaugurado oficialmente no início de 1821, constituiria, no decorrer do século XIX, um importante centro de instrução e de formação sacerdotal. E, da mesma maneira que o Seminário de Nossa Senhora da Boa Morte, formaria homens, tanto leigos quanto eclesiásticos, que se destacariam na vida política do Brasil: “(...) Nos nossos colégios haverão (sic) aqueles estudos que se julgarem preliminares não somente para os moços que aspirarem ao estado eclesiástico, mas também à magistratura (...).,"110

Entre os eclesiásticos que estudaram no Seminário do Caraça, destacam-se: D. Joaquim Silvério de Sousa ${ }^{111}$, arcebispo de Diamantina; e D. Modesto Augusto Vieira ${ }^{112}$, bispo auxiliar de Mariana. E, passaram pelo Colégio do Caraça, homens que ocupariam posições importantes no campo político brasileiro, entre os quais: Afonso Pena ${ }^{113}$ e Artur Bernardes ${ }^{114}$, ambos presidentes da Província de Minas e, posteriormente, da República.

Porém, o Seminário de Mariana, não ficaria atrás, pois, continuou formando indivíduos que se tornariam personalidades de destaque no período republicano, tanto no interior da Igreja, quanto na vida política, como: Carlos Carmelo de Vasconcelos Mota ${ }^{115}$, cardeal de São Paulo, e Delfim Moreira ${ }^{116}$, presidente da República.

Ainda na primeira metade do século XIX, esse colégio vai se destacando no cenário educacional do Império: em 1824, esse estabelecimento recebeu de D. Pedro I, o título de Imperial, e possuía oitenta e cinco alunos; no ano seguinte o número subiu para cento e treze; e um pouco depois para cento e cinquenta. Entre 1821 e 1835 estudaram nessa instituição mais de mil alunos.

Em 1842, o mesmo movimento revolucionário que atingiu o Seminário de Nossa Senhora da Boa Morte, ameaçou o Colégio do Caraça. Nesse cenário, sua administração resolveu transferi-lo para longe do foco da revolução: para Campo Belo, no Triângulo Mineiro. ${ }^{117}$ Os estudantes foram uns, para suas famílias, e outros para o Colégio de Congonhas. ${ }^{118}$

Nessa época, diante da dificuldade de achar um número suficiente de padres, na diocese de Mariana, que tivessem as habilitações precisas para administrar o Seminário de Nossa Senhora da Boa Morte ${ }^{119}$, D. Viçoso manifesta seu desejo de entregar tal estabelecimento aos lazaristas, seus co-irmãos, enviando um desses padres a Paris, com o objetivo de negociar com o Superior Geral da Congregação da Missão, a vinda de congregados para a diocese de Mariana.

Em 1849, com a permissão do governo civil, chegaram da França alguns congregados da Ordem de São Vicente de Paulo. Um deles, o padre Chanavat, começou a reger, no Seminário de Mariana, a cadeira de Teologia Dogmática: “(...) Era, enfim, chegado o tempo de se traduzirem (sic) em realidade: (...) a entrega do Seminário à (...) Congregação da Missão(...)." (FREITAS, 1979, p.228)

Nesse quadro, de acordo com Carvalho (1981), os seminários episcopais no Brasil (a exemplo do Seminário de Mariana) viviam com dificuldades e, na falta de elementos nacionais adequados, os bispos se viram obrigados a recorrer a padres estrangeiros para administrar esses estabelecimentos $^{120}$.

Em 1853, os lazaristas assumem a direção do Seminário Maior, embora no início tenham surgido algumas dificuldades entre professores e alunos, tais como as diferenças de língua e de hábitos, mas, conforme Trindade (1953) com o tempo tudo se acomodou. Por essa época, Mariana foi assolada por uma epidemia de varíola. Então, o bispo e os professores, em conselho, resolveram transferir os estudantes do Seminário Menor para uma fazenda da diocese. Os seminaristas maiores foram para o Caraça, onde, após doze anos de abandono, começava uma nova era, pois ao colégio era acrescido o Seminário Maior: formador do clero mineiro.

Um ano depois, D. Viçoso passa a administração do Seminário Menor a seus co-irmãos. No entanto, durante algum tempo, a direção do Seminário de Mariana pelos lazaristas se 
manteve provisória. Em 1859 o estabelecimento fundado por D. Frei Manuel da Cruz e reformado por D. Viçoso seria entregue definitivamente aos padres da Congregação da Missão. A entrega solene se efetuou em 1863, sob a autorização da Santa Sé e o consentimento do Cabido. A partir daí até a década de sessenta do século XX, o Seminário de Mariana (Maior e Menor) ficaria sob a direção dos lazaristas:

(...) Fazemos a solene entrega do nosso Seminário Episcopal aos Rmos. PP. da Congregação da Missão, afim de que o dirijam, eduquem e instruam a mocidade que se destina ao estado eclesiástico, assim como nos estudos preparatórios a que se chamam Seminário Menor, como nos estudos Eclesiásticos, a que chamam Seminário Maior, do mesmo modo que o costumam fazer nos Seminários a eles confiados (...) em outros países e como até agora o tem feito neste Bispado, recebi os relatórios, emolumentos e gratificações com que sua Majestade se dignar a concorrer, para esta obra que tanto interessa à Igreja e ao Estado. ${ }^{121}$

Quanto ao Caraça, este, ao longo dos séculos XIX e XX, prosseguiu com suas atividades, somente interrompidas logo após um incêndio, ocorrido no dia 28 de maio de 1968, o qual destruiu um pavilhão de três andares. Daí os alunos, cerca de noventa, se foram; os professores transferiram-se para outros colégios ou seminários; as irmãs vicentinas que ali atuavam desde 1951, partiram para suas creches e hospitais; e os empregados foram indenizados e se retiraram. Depois do incêndio, os lazaristas pensaram em reconstruir o prédio, e chamar de volta os alunos. No entanto: “(...) a dificuldade de verbas, as discussões com os especialistas do Patrimônio Histórico e, principalmente as mudanças da Igreja com relação à formação de sacerdotes, fizeram que depressa eles mudassem de idéia (...).”(ZICO, 1979, p.262)

Mas, aos poucos, com o auxílio de órgãos públicos e empresas, foram empreendidas obras de conservação e restauração do Caraça: asfaltamento da estrada; restauração da ala direita da frente, de parte do prédio do incendiado e do refeitório; instalação do sistema de tratamento de esgotos; construção da cozinha industrial; entre outros melhoramentos. Em 1994, por meio de uma Portaria, a área do Caraça foi transformada em Reserva Particular do Patrimônio Natural. Atualmente, o Caraça funciona como local de estudos, repouso e turismo.

A partir da abordagem acerca do Seminário de Nossa Senhora da Boa Morte, verifica-se que este estabelecimento não teve uma história pacífica: oscilou entre períodos de prosperidade e de decadência; constituiu objeto de interesse dos poderes públicos; foi temporariamente desviado de suas funções primordiais (transformado em quartel); e diante da necessidade de se sustentar, foi obrigado a admitir pensionistas, cujo número se manteve superior ao dos recebidos titulo paupertatis e, essa desproporção constituiu um distanciamento, por parte dessa instituição, dos decretos conciliares, não obstante seu caráter tridentino.

\section{REFERÊNCIAS}

Almanaque Abril. Quem é quem na história do Brasil. São Paulo: Abril Multimídia, 2000.

Alvará de 2 de maio de 1747. TRINDADE, Raimundo. Arquidiocese de Mariana. Subsídios para sua história. Belo Horizonte: Imprensa Oficial, 1953, v.1.

Alvará régio, de 28 de junho de 1759, em que se extinguem todas as Escolas reguladas pelo método dos Jesuítas e se estabelece um novo regime. Diretor dos Estudos, Professores de Gramática Latina, de Grego e Retórica. In: ALVES, Gilberto Luiz. Educação e história em Mato Grosso: 1719-1864. Campo Grande: UFMS/ Imprensa Universitária, 1984.

ALVES, Gilberto Luiz. O Seminário de Olinda. In: LOPES, Eliane Marta T. et. al. 500 anos de educação no Brasil. Belo Horizonte: Autêntica, 2003.

AZZI, Riolando. A instituição durante a primeira época colonial. In: HOORNAERT, Eduardo. História da Igreja no Brasil. Petrópolis: Vozes, 1977, tomo II, v.1.

BELLOCH, Ismael; ABREU, Alzira Alves de. Dicionário histórico e biográfico brasileiro (19301983). Rio de Janeiro: Forense Universitária. FGV/CPDOC, 1984. 
BOSCHI, Caio César. Os leigos e o poder. Irmandades leigas e política colonizadora em Minas Gerais. São Paulo: Ática, 1986.

Bula de Bento XIV, referente à eleição e confirmação de D. Frei Manuel da Cruz como bispo da nova diocese de Mariana (1745). TRINDADE, Raimundo. Arquidiocese de Mariana. Subsídios para sua história. Belo Horizonte: Imprensa Oficial, 1953, v.1, p. 94

CALDEIRA, Jorge (Org.). Diogo Antônio Feijó. Formadores do Brasil. São Paulo: Editora 34, 1999.

CALMON, Pedro. História do Brasil. Rio de Janeiro: José Olympio, 1959, v. 4.

CAMELO, Maurílio José de Oliveira. Dom Antônio Ferreira Viçoso e a reforma do clero em Minas Gerais no século XIX. Tese de Doutorado. São Paulo: FFLCH/USP, 1986.

CARRATO, José Ferreira. Igreja, iluminismo e escolas mineiras coloniais. São Paulo: Companhia Editora Nacional, 1968.

Carta de D. Frei José da Santíssima Trindade ao Ministro Thomaz Antônio de Vila Nova Portugal (1820). TRINDADE, Raimundo. Arquidiocese de Mariana. Subsídios para sua história. São Paulo: Escolas Profissionais do Liceu Coração de Jesus, 1929, v.2.

Carta de D. Frei José da Santíssima Trindade ao Núncio Apostólico (1830). TRINDADE, Raimundo. Arquidiocese de Mariana. Subsídios para sua história. Belo Horizonte: Imprensa Oficial, 1953, v.1.

Carta de D. Frei Manuel da Cruz a D. João V, rei de Portugal (1747). Pasta de D. Frei Manuel da Cruz. Armário 1. Gaveta 1. Arquivo Eclesiástico da Arquidiocese de Mariana.

Carta de D. Frei Manuel da Cruz (1749). Pasta de D. Frei Manuel da Cruz. Armário 1. Gaveta 1. Arquivo Eclesiástico da Arquidiocese de Mariana.

Carta de D. Frei Manuel da Cruz a El-Rei pelo Conselho Ultramarino (1753). Pasta de D. Frei Manuel da Cruz. Armário 1. Gaveta 1. Arquivo Eclesiástico da Arquidiocese de Mariana.

Carta de D. Frei Manuel da Cruz ao Padre Malagrida (1756). TRINDADE, Raimundo. Arquidiocese de Mariana. Subsídios para sua história, 1953, v.1.

Carta de D. Frei Manuel da Cruz ao Secretário do Estado de Ultramar (1758). TRINDADE, Raimundo. Arquidiocese de Mariana. Subsídios para sua história. Belo Horizonte: Imprensa Oficial, 1953, v. 1.

Carta para o Reverendíssimo Padre José Moreira, Confessor D’El Rei, Nosso Senhor (1751). Pasta de D. Frei Manuel da Cruz. Armário 1. Gaveta 1. Arquivo Eclesiástico da Arquidiocese de Mariana.

Carta Régia (1820). TRINDADE, Raimundo. Arquidiocese de Mariana. Subsídios para sua história. São Paulo: Escolas Profissionais do Liceu Coração de Jesus, 1929, v.2.

CARVALHO, José Murilo de. A construção da ordem. A elite política imperial. Brasília: Editora da Universidade de Brasília, 1981.

CARVALHO, Laerte Ramos de. A educação e seus métodos. In: HOLANDA, Sérgio Buarque de (Dir.)

História geral da civilização brasileira. A época colonial. Administração, economia e sociedade. Rio de Janeiro: Bertrand Brasil, 2003, t. I, v. 2.

COELHO, José João Teixeira. Instrução para o governo da Capitania de Minas Gerais. Belo Horizonte: Fundação João Pinheiro, 1994.

Cópia do Testamento do Irmão Lourenço (1806). Pasta de D. Frei Cipriano de São José. Armário 2. Gaveta 1. Arquivo Eclesiástico da Arquidiocese de Mariana.

Dicionário biográfico universal. São Paulo: Três, 1984, v. 6.

Edital de D. Frei Cipriano de São José sobre o Seminário (1800). TRINDADE, Raimundo. Arquidiocese de Mariana. Subsídios para sua história. Belo Horizonte: Imprensa Oficial, 1955, v. 2.

Edital sobre o Seminário de Nossa Senhora da Boa Morte de Mariana (1764). TRINDADE, Raimundo. Arquidiocese de Mariana. Subsídios para sua história. São Paulo: Escolas Profissionais do Liceu Coração de Jesus, 1929, v. 2. 
Estatutos para o Regimento do Seminário Menor de Nossa Senhora da Boa Morte (1760). TRINDADE, Raimundo. Arquidiocese de Mariana. Subsídios para sua história. Belo Horizonte: Imprensa Oficial, 1953, v. 1.

Estatutos para o Regime do Seminário Episcopal de Nossa Senhora da Boa Morte, da Leal Cidade de Mariana, no Ano de 1821. Pasta de D. Frei José da Santíssima Trindade. Armário 2. Gaveta 2. Arquivo Eclesiástico da Arquidiocese de Mariana.

FALCON, Francisco José Calazans. A época pombalina. Política econômica e monarquia ilustrada. São Paulo: Ática, 1982.

FRAGOSO, Hugo. Uma contribuição para a história vocacional da província franciscana de Santo Antônio. In: AZZI, Riolando (Org.). A vida religiosa no Brasil. Enfoques históricos. São Paulo: Paulinas, 1983.

FREITAS, José Higino de. Aplicação no Brasil do decreto tridentino sobre os seminários até 1889. Belo Horizonte: São Vicente, 1979.

Grande Enciclopédia Delta-Larousse. Rio de Janeiro: Delta, 1973.

GUIMARÃES, Archimedes Pereira. Padre Belchior. E agora Padre Belchior? Belo Horizonte, 1972.

HANSEN, João Adolfo. Ratio Studiorum e política católica ibérica no século XVII. In: VIDAL, Diana Gonçalves; HILSDORF, Maria Lúcia Spedo. Brasil 500 anos: tópicas em História da Educação. São Paulo: Edusp, 2001.

HOORNAERT, Eduardo. História da Igreja no Brasil.. Petrópolis: Vozes, 1992, t. II, v.1.

LEITE, Serafim. História da Companhia de Jesus no Brasil. Belo Horizonte-Rio de Janeiro: Itatiaia, 2000, t.I.

Livro de Matrículas do Seminário de Nossa Senhora da Boa Morte (1792-1848). Armário IV. Arquivo Eclesiástico da Arquidiocese de Mariana.

LUZ, Nícia Vilela. Inquietação revolucionária no Sul: Conjuração Mineira. In: HOLANDA, Sérgio Buarque de (Dir.). História geral da civilização brasileira. A época colonial. Administração, economia , sociedade. Rio de Janeiro: Bertrand Brasil, 2003, tomo I, v. 2

MICELI, Sérgio. A elite eclesiástica brasileira. Rio de Janeiro: Bertrand Brasil, 1988.

MOUSNIER, Roland. Os séculos XVI e XVII. Os progressos da civilização européia. In: CROUZET, MAURICE (Dir.). História geral das civilizações. São Paulo: Difusão Européia do Livro, 1957, v. IX.

; LABROUSSE, Ernest. O século XVIII. O último século do Antigo Regime. In: CROUZET, Maurice (Dir.). História geral das civilizações, 1957, v. XI.

O Seminário de Mariana em 1831. Revista do Arquivo Público Mineiro. Ano IV. Belo Horizonte: Imprensa Oficial, 1899.

OLIVEIRA, Ronald Polito de. Estudo introdutório. Visitas pastorais de D. Frei José da Santíssima Trindade. Belo Horizonte: Fundação João Pinheiro. Centro de Estudos Históricos e Culturais. Instituto do Patrimônio Histórico e Artístico de Minas Gerais, 1998.

Ordem de expulsão (1758). TRINDADE, Raimundo. Arquidiocese de Mariana. Subsídios para sua história. Belo Horizonte: Imprensa Oficial, 1953, v.1.

Ordem Régia para a fundação do Seminário (1748). Pasta de D. Frei Manuel da Cruz. Armário 1. Gaveta 1. Arquivo Eclesiástico da Arquidiocese de Mariana.

PASIN, José Luiz. Os barões do café. Aparecida: Santuário, 2001.

Pastoral de D. Antônio Ferreira Viçoso aos Filhos do Colégio Episcopal. PIMENTA, Silvério Gomes.

Vida de D. Antônio Ferreira Viçoso. Mariana: Tipografia Arquiepiscopal, 1920.

Pastoral sobre o Seminário (1772). TRINDADE, Raimundo. Arquidiocese de Mariana. Subsídios para sua história. . São Paulo: Escolas Profissionais do Liceu Coração de Jesus, 1929, v. 2. 
PIMENTA, Silvério Gomes. Vida de D. Antônio Ferreira Viçoso. Mariana: Tipografia Arquiepiscopal, 1920.

Projeto de um Colégio de Artes e Disciplinas Eclesiásticas no edifício do Seminário (1816). TRINDADE, Raimundo. Arquidiocese de Mariana. Subsídios para sua história, 1953, v. 1

Provisão da entrega do Seminário de Mariana aos Padres da Congregação da Missão (1863).

TRINDADE. Raimundo. Arquidiocese de Mariana. Subsídios para sua história, 1929, v.2.

Regimento do Colégio do Caraça. Capítulo IV, § 1. ZICO, José Tobias. Caraça, peregrinação, cultura e turismo. Contagem: Littera Maciel, 1988.

Relatório de D. Frei José da Santíssima Trindade (1827). Pasta De D. Frei José da Santíssima Trindade. Armário 1. Gaveta 2. Arquivo Eclesiástico da Arquidiocese de Mariana.

Relatório do Episcopado de Mariana (Governo de D. Frei Manuel da Cruz) para a Sagrada Congregação do Concílio de Trento (1757). Pasta de D. Frei Manuel da Cruz. Armário 1. Gaveta 1. Arquivo Eclesiástico da Arquidiocese de Mariana.

SAINT-HILAIRE, Auguste de. Viagem pelas províncias do Rio de Janeiro e Minas Gerais. Belo Horizonte: Itatiaia; São Paulo: Editora da Universidade de São Paulo, 1975.

Seminário (1806). Pasta de D. Frei Cipriano de São José. Armário 2. Gaveta 1. Arquivo Eclesiástico da Arquidiocese de Mariana.

SOUZA, João Evangelista de. Catas Altas do Mato Dentro. Sua história e sua gente. Contagem: Littera Maciel, 1998, v.1.

SOUZA, Joaquim Silvério de. Sítios e personagens. Belo Horizonte: Imprensa Oficial, 1930.

Termos de Ordenações (1801-1837). Armário IV. Arquivo Eclesiástico da Arquidiocese de Mariana.

Termos de Ordenações (1749-1793). Armário IV. Arquivo Eclesiástico da Arquidiocese de Mariana.

TRINDADE, D. Frei José da Santíssima. O Seminário de Mariana em 1831. Revista do Arquivo Público Mineiro, ano IV. Fascículos III e IV, jul. a dez. 1899. Belo Horizonte: Imprensa Oficial, 1900.

TRINDADE, Raimundo. Arquidiocese de Mariana. Subsídios para sua história. São Paulo: Escolas Profissionais do Liceu Coração de Jesus, 1929, v. 2.

1953, v.1. Arquidiocese de Mariana. Subsídios para sua história. Belo Horizonte: Imprensa Oficial,

1955, v.2.

Arquidiocese de Mariana. Subsídios para sua história. Belo Horizonte: Imprensa Oficial,

Breve notícia dos Seminários de Mariana. Belo Horizonte: Imprensa Oficial, 1955.

VASCONCELOS, Diogo de. História do Bispado de Mariana. Belo Horizonte: Biblioteca Mineira de Cultura, 1935.

VEIGA, João Pedro Xavier da. Efemérides mineiras. Belo Horizonte: Centro de Estudos Históricos Culturais. Fundação João Pinheiro, 1998.

VENARD. Marc. O Concílio Lateranense e o Tridentino. In: ALBERIGO, Giuseppe (Org.) História dos Concílios Ecumêmicos. São Paulo: Papirus, 1995.

VIDE, Sebastião Monteiro da. Constituições do Arcebispado da Bahia (1707). Coimbra: Real Colégio das Artes, 1710. Museu do Livro. Biblioteca dos Bispos Marianenses.

VIEIRA, David Gueiros. O protestantismo, a maçonaria e a Questão Religiosa no Brasil. Brasília: Editora Universidade de Brasília, 1980.

VIEIRA, Dorival Teixeira. Política financeira - o primeiro Banco do Brasil. In: HOLANDA, Sérgio Buarque de (Dir.). História Geral da Civilização Brasileira. O processo de emancipação. Rio de Janeiro: Bertrand Brasil, 2003, t. II, v.3.

ZICO, José Tobias. Caraça: ex-alunos e visitantes. Belo Horizonte: São Vicente, 1979. 


\section{Notas}

${ }^{1}$ Mestre em Educação pelo Programa de Pós-Graduação em Educação da Universidade Federal de São Carlos (UFSCar -
Bolsista da CAPES). Graduado em História pelo Instituto de Ciências Humanas e Sociais (ICHS) da Universidade Federal de Ouro Preto (UFOP).

${ }^{2}$ Doutor em Educação, Docente do Departamento de Educação e do Programa de Pós-Graduação em Educação da Universidade Federal de São Carlos, Líder do Grupo de Pesquisa "Educação e Direito na Sociedade Brasileira Contemporânea", Pesquisador sobre Educação Jurídica no Brasil, home Page: www.educardireito.com.br

${ }^{3}$ Na Sessão XXIII, Capítulo 18, do Concílio de Trento, ordena-se aos bispos que abram colégios que serão como sementeiras (seminários), onde os jovens pobres serão acolhidos para aprenderem gratuitamente o Latim e serem formados para a vida clerical. VENARD. Marc. O Concílio Lateranense e o Tridentino. In: ALBERIGO, Giuseppe (Org.) História dos Concílios Ecumêmicos, 1995, p. 345.

${ }^{4}$ Bula de Bento XIV, referente à eleição e confirmação de D. Frei Manuel da Cruz como bispo da nova diocese de Mariana (1745). TRINDADE, Raimundo. Arquidiocese de Mariana. Subsídios para sua história. 1953, v.1, p. 94.

${ }^{5}$ Carta de D. Frei Manuel da Cruz a D. João V, rei de Portugal (1747). Pasta de D. Frei Manuel da Cruz. Armário 1. Gaveta 1. Arquivo Eclesiástico da Arquidiocese de Mariana. Optou-se pela atualização da ortografia.

${ }^{6}$ Relatório do Episcopado de Mariana (Governo de D. Frei Manuel da Cruz) para a Sagrada Congregação do Concílio de Trento (1757). Pasta de D. Frei Manuel da Cruz. Armário 1. Gaveta 1. Arquivo Eclesiástico da Arquidiocese de Mariana.

${ }^{7}$ Ordem Régia para a fundação do Seminário (1748). Pasta de D. Frei Manuel da Cruz. Armário 1. Gaveta 1. Arquivo Eclesiástico da Arquidiocese de Mariana.

${ }^{8}$ Um dos alunos, Luiz Vieira da Silva, o qual estaria envolvido mais tarde, no movimento denominado Inconfidência Mineira, matriculou-se no Seminário de Nossa Senhora da Boa Morte, em agosto de 1750, aproximadamente quatro meses antes de sua fundação oficial. TRINDADE, Raimundo. Arquidiocese de Mariana. Subsídios para sua história, 1953, v.1, p. 383.

${ }^{9}$ O Recolhimento de Macaúbas, foi fundado por Félix da Costa, em Jaboticatubas, antiga comarca de Sabará, em 1716, e recebeu inicialmente doze donzelas, sete das quais, irmãs e sobrinhas do fundador. SOUZA, Joaquim Silvério de. Sítios e personagens, 1930, p. 257.

${ }^{10}$ O Colégio dos Padres Osório, situado na freguesia de Nossa Senhora do Rosário do Sumidouro, nas proximidades de Mariana, foi fundado, provavelmente, pelo padre Bento Cardoso Osório. CARRATO, José Ferreira. Igreja, iluminismo e escolas mineiras coloniais. São Paulo: Companhia Editora Nacional, 1968, p. 120. Mais tarde, os irmãos do padre Bento, entre os quais Joaquim da Cunha Osório, Francisco da Cunha Osório e Manuel da Cunha Osório, lecionaram nesse Colégio. TRINDADE, Raimundo. Arquidiocese de Mariana. Subsídios para sua história, 1955, v. 2, p. 101.

${ }^{11}$ Nasceu em Peniche, localidade próxima a Lisboa, em 1787. Concluiu as letras primárias e iniciou o estudo de Latim no convento dos carmelitas de Olhalvo, perto de Peniche. Em 1811, vestiu o hábito de São Vicente de Paulo. Ordenado padre, em 1818, tornou-se, professor de Filosofia em Évora. No ano seguinte, D. João VI encarregado da catequese dos índios do Mato Grosso. E para tal missão são designados dois vicentinos: Leandro Rabelo Peixoto e Castro e Antônio Ferreira Viçoso. Porém, logo que esses dois padres chegam ao Rio de Janeiro, D. João VI, confia-lhes outra missão: o estabelecimento de uma residência de missionários e de um colégio para meninos, na serra do Caraça, em Minas Gerais. Deste modo, a missão de catequizar os indígenas de Mato Grosso foi entregue a um capuchinho. A partir dos esforços dos dois vicentinos, nasce o Colégio e Seminário do Caraça. Em 1843, desempenhando a função de Superior da Congregação da Missão no Brasil, Antônio Ferreira Viçoso, recebe o aviso imperial que o fazia bispo de Mariana, tomando posse em 1844 e permanecendo no governo dessa diocese até sua morte, em 1875. TRINDADE, Raimundo. Arquidiocese de Mariana. Subsídios para sua história, 1953, v. 1, pp. 218-220; 236.

12 Tal capela foi construída no início da década de 1780, por ordem do então bispo de Mariana, D. Domingos da Encarnação Pontével. TRINDADE, Raimundo. Arquidiocese de Mariana. Subsídios para sua história., 1953, v. 1,p. 391

${ }^{13}$ Repartição Fiscal da Capitania, situada além da chamada rua da Olaria. O edifício onde funcionou a Intendência foi adaptado para acolher o Seminário de Nossa Senhora da Boa Morte. TRINDADE, Raimundo. Arquidiocese de Mariana. Subsídios para sua história, 1953, v. 1, pp.374-375; 391.

${ }^{14}$ Provavelmente o curso de Filosofia começou a funcionar no Seminário de Mariana por volta de 1758, pois de acordo com um relatório elaborado em 1757 por D. Frei Manuel da Cruz: “ (...) em breve (os alunos) estudarão Filosofia, se concedida a licença régia, por mim solicitada com empenho". Relatório do Episcopado de Mariana (Governo de D. Frei Manuel da Cruz) para a Sagrada Congregação do Concílio de Trento (1757). Pasta de D. Frei Manuel da Cruz. Armário 1. Gaveta 1. Arquivo Eclesiástico da Arquidiocese de Mariana. E, em 1758, já havia o curso de Filosofia, pois no cenário das perseguições de Pombal aos jesuítas, o primeiro bispo de Mariana foi obrigado a despedir o professor que ministrava tal curso. TRINDADE, Raimundo. Arquidiocese de Mariana. Subsídios para sua história, 1953, v. 1, p. 382.

${ }^{15}$ É de uso frequente, no velho idioma português, o plural casas, na acepção de um só edifício. Assim, casa pode significar tanto edifício, morada, quanto seus cômodos: casa de jantar, de dormir, etc. TRINDADE, Raimundo. Arquidiocese de Mariana. Subsídios para sua história, 1953, v.1, p. 78.

${ }^{16}$ Tal chácara passou, a partir de 1753, a ser residência de D. Frei Manuel da Cruz, transformando-se, assim, em Palácio Episcopal. TRINDADE, Raimundo. Arquidiocese de Mariana. Subsídios para sua história, 1953, v.1, p. 119. 
${ }^{17}$ Quintanilha fez a doação com o ônus de três missas por semana a serem celebradas perpetuamente na capela do seminário e às custas deste. Também viveria nesse estabelecimento gratuitamente até sua ordenação, ou morte. TRINDADE, Raimundo. Arquidiocese de Mariana. Subsídios para sua história, 1953, v.1, p. 374.

${ }^{18}$ Provisão da Fundação do Seminário (1750). TRINDADE, Raimundo. Arquidiocese de Mariana. Subsídios para a sua história, 1953, v.1, p. 376.

${ }^{19}$ Carta de D. Frei Manuel da Cruz a El-Rei D. José I pelo Conselho Ultramarino (1753). TRINDADE, Raimundo. Arquidiocese de Mariana. Subsídios para sua história, 1953, v. 1, pp. 378-379.

${ }^{20}$ Todos os bispos, até D. Antônio Ferreira Viçoso (este até 1850) pagavam ao Seminário de Mariana os aluguéis do Palácio Episcopal. TRINDADE, Raimundo. Arquidiocese de Mariana. Subsídios para sua história, 1953, v. 1, p. 391.

${ }^{21}$ Francisco Inácio Marcondes Homem de Melo nasceu em Pindamonhangaba, São Paulo, em 1837. Pertenceu à elite paulista. Seu pai, Francisco Marcondes Homem de Melo foi abastado fazendeiro e coronel comandante da Guarda Nacional, e ainda recebeu o título nobiliárquico de Visconde de Pindamonhangaba. PASIN, José Luiz. Os barões do café. Estudou Humanidades no Seminário de Mariana. TRINDADE, Raimundo. Breve notícia dos Seminários de Mariana, 1955, p. 242. Formou-se em Direito pela Faculdade de São Paulo. Iniciou-se na política como membro do Partido Liberal e elegeu-se vereador e posteriormente presidente da Câmara Municipal de Pindamonhangaba. Foi presidente de várias Províncias: São Paulo, Ceará, Rio Grande do Sul e Bahia. Ministro da Guerra e Conselheiro do Imperador. Recebeu o título de Barão Homem de Melo. Também teve atuação no campo intelectual, publicando obras como O Atlas do Império do Brasil e como presidente do Instituto Histórico e Geográfico do Brasil e da Sociedade de Geografia do Rio de Janeiro. Faleceu em Campo Belo, Minas Gerais, em 1918. Dicionário biográfico universal, 1984, v. 6, p. 383

${ }^{22}$ Livro de Matrículas do Seminário de Nossa Senhora da Boa Morte (1792-1848). Armário IV. Arquivo Eclesiástico da Arquidiocese de Mariana. Embora conste o ano de 1792, existem nesse mesmo livro, registros de matrículas referentes aos anos de 1790 e 1791.

${ }^{23}$ Estatutos para o Regime do Seminário Episcopal de Nossa Senhora da Boa Morte, da Leal Cidade de Mariana, no Ano de 1821. Pasta de D. Frei José da Santíssima Trindade. Armário 2. Gaveta 2. Arquivo Eclesiástico da Arquidiocese de Mariana.

${ }^{24}$ Livro de Matrículas do Seminário de Nossa Senhora da Boa Morte (1792-1848). Armário IV. Arquivo Eclesiástico da Arquidiocese de Mariana.

${ }^{25}$ Livro de Matrículas do Seminário de Nossa Senhora da Boa Morte (1792-1848). Armário IV. Arquivo Eclesiástico da Arquidiocese de Mariana.

${ }^{26}$ Nasceu no Porto, em 1762. Iniciou-se nas letras secundárias no seminário episcopal de sua cidade natal. Aos dezesseis anos vestiu o hábito franciscano, no convento de Santo Antônio, na Bahia. Foi professor, mestre de noviços e vigário provincial, entre outras funções. Em 1819, foi confirmado por bulas, bispo de Mariana, onde entrou solenemente no ano seguinte. Faleceu em Mariana, em 1835. TRINDADE, Raimundo. Arquidiocese de Mariana. Subsídios para sua história, 1953, v. 1, pp. 182-186; 202.

${ }^{27}$ Estatutos para o Regime do Seminário Episcopal de Nossa Senhora da Boa Morte, da Leal Cidade de Mariana, no Ano de 1821. Pasta de D. Frei José da Santíssima Trindade. Armário 2. Gaveta 2. Arquivo Eclesiástico da Arquidiocese de Mariana.

${ }^{28}$ Relatório de D. Frei José da Santíssima Trindade (1827). Pasta De D. Frei José da Santíssima Trindade. Armário 1. Gaveta 2. Arquivo Eclesiástico da Arquidiocese de Mariana.

${ }^{29}$ Livro de Matrículas do Seminário de Nossa Senhora de Boa Morte (1792-1848). Armário IV. Arquivo Eclesiástico da Arquidiocese de Mariana. No Seminário de Mariana, esses ofícios e também o de porteiro eram privativos desses alunos. Estatutos para o Regime do Seminário Episcopal de Nossa Senhora da Boa Morte, da Leal Cidade de Mariana, no Ano de 1821. Pasta de D. Frei José da Santíssima Trindade. Armário 2. Gaveta 2. Arquivo Eclesiástico da Arquidiocese de Mariana.

${ }^{30}$ Seminário (1806). Pasta de D. Frei Cipriano de São José. Armário 2. Gaveta 1. Arquivo Eclesiástico da Arquidiocese de Mariana.

${ }^{31}$ Relatório de D. Frei José da Santíssima Trindade (1827). Pasta de D. Frei José da Santíssima Trindade. Armário 1. Gaveta 2. Arquivo Eclesiástico da Arquidiocese de Mariana.

${ }^{32}$ Ofício de 12 de janeiro de 1835, assinado pelo Reitor João Antônio de Oliveira. TRINDADE, Raimundo. Arquidiocese de Mariana. Subsídios para sua história, 1953, v.1, p. 403

${ }^{33}$ Nos tempos coloniais, por exemplo, verifica-se no Seminário de São José, no Rio de Janeiro, que o número dos pensionistas era maior do que o dos alunos pobres. No Seminário de Santo Alexandre, no Pará, o número de pobres não era grande, diante da precária situação financeira dessa instituição, onde em 1830, já no período monárquico, o número dos alunos titulo paupertatis era menos da metade do que o dos pensionistas. FREITAS, José Higino de. Aplicação no Brasil do decreto tridentino sobre os seminários até 1889, 1979, pp. 185-217

${ }^{34}$ Carta para o Reverendíssimo Padre José Moreira, Confessor D’El Rei, Nosso Senhor (1751). Pasta de D. Frei Manuel da Cruz. Armário 1. Gaveta 1. Arquivo Eclesiástico da Arquidiocese de Mariana.

${ }^{35}$ Carta para o Reverendíssimo Padre José Moreira, Confessor D’El Rei, Nosso Senhor (1751). Pasta de D. Frei Manuel da 
Cruz. Armário 1. Gaveta 1. Arquivo Eclesiástico da Arquidiocese de Mariana.

36 Além dos jesuítas e dos padres da Congregação da Missão, outros religiosos regulares administraram, por um determinado período, alguns seminários brasileiros, como o Seminário da Bahia, administrado, entre 1852 e 1856 , por um beneditino e o Seminário de São Paulo, dirigido pelos capuchinhos, entre as décadas de 50 e 70 do século XIX. FREITAS, José Higino de. Aplicação no Brasil do decreto tridentino sobre os seminários até 1889, 1979, pp. 232; 235.

${ }^{37}$ Contudo, considerando o trecho da carta de D. Frei Manuel da Cruz ao padre José Moreira, datada de 1751, em que se lê que o curso de Filosofia não havia se principiado por falta de mestres, torna-se difícil entender por que o padre José Nogueira não ministrou, no Seminário de Nossa Senhora da Boa Morte, tal disciplina, “(...) em que é perito, e mestre pela láurea conquistada na Companhia (...).” Carta de D. Frei Manuel da Cruz (1749). Pasta de D. Frei Manuel da Cruz. Armário 1. Gaveta 1. Arquivo Eclesiástico da Arquidiocese de Mariana. E, em 1751 o padre José Nogueira já atuava como professor no Seminário de Mariana, mas não de Filosofia, e sim de Teologia Moral e Latim. E também é difícil compreender por que tal Seminário, dispondo, desde antes de sua fundação, de um mestre de Filosofia, este curso começou a funcionar nessa instituição, somente por volta de 1758 .

${ }^{38}$ Carta de D. Frei Manuel da Cruz (1749). Pasta de D. Frei Manuel da Cruz. Armário 1. Gaveta 1. Arquivo Eclesiástico da Arquidiocese de Mariana.

${ }^{39}$ No dia 26 de dezembro de 1753, o padre jesuíta José Geraldes, Provincial do Brasil, dirigia-se a D. José I, rogando-lhe que houvesse por bem suprir aos membros da Companhia de Jesus, que mandava para Mariana, no que lhes faltasse para a nova fundação. E, tal rogativa gerou a referida carta de D. Frei Manuel da Cruz ao rei de Portugal. A partir daí pode-se afirmar que esta carta foi escrita depois da ordem régia que autorizou a vinda dos jesuítas para Mariana. TRINDADE, Raimundo. Arquidiocese de Mariana. Subsídios para sua história, 1953, v.1, p. 378.

${ }^{40}$ Carta de D. Frei Manuel da Cruz a El-Rei pelo Conselho Ultramarino (1753). Pasta de D. Frei Manuel da Cruz. Armário 1. Gaveta 1. Arquivo Eclesiástico da Arquidiocese de Mariana.

${ }^{41}$ Carta de D. Frei Manuel da Cruz ao Padre Malagrida (1756). TRINDADE, Raimundo. Arquidiocese de Mariana. Subsídios para sua história, 1953, v.1, p. 381.

${ }^{42}$ É curioso verificar o estabelecimento de uma residência de jesuítas no interior de uma Capitania onde estava proibida a fixação de ordens religiosas. Nesse compasso, Boschi se refere à presença dos padres da Companhia de Jesus em Minas, na época da referida proibição, assim como de outros religiosos regulares, entre os quais os franciscanos e os capuchinhos. BOSCHI, Caio César. Os leigos e o poder. Irmandades leigas e política colonizadora em Minas Gerais, 1986, p. 83.

${ }^{43}$ Não se sabe ao certo quando o padre José Nogueira saiu de Mariana, mas, em 1757 já se encontrava no Rio de Janeiro, onde exercia o cargo de procurador e de lente substituto de Sagrada Escritura. Foi preso em 1759 e deportado em 1760 para Lisboa. TRINDADE, Raimundo. Arquidiocese de Mariana. Subsídios para sua história, 1953, v.1, p.418.

${ }^{44}$ Ordem de expulsão (1758). TRINDADE, Raimundo. Arquidiocese de Mariana. Subsídios para sua história, 1953, v.1, p. 129.

${ }^{45}$ Trata-se do padre Manuel Tavares, sucessor do padre José Nogueira na reitoria do Seminário. TRINDADE, Raimundo. Arquidiocese de Mariana. Subsídios para sua história, 1953, v.1, p. 129.

${ }^{46}$ Carta de D. Frei Manuel da Cruz ao Secretário do Estado de Ultramar (1758). TRINDADE, Raimundo. Arquidiocese de Mariana. Subsídios para sua história, 1953, v. 1, p. 129.

${ }^{47}$ Alvará régio, de 28 de junho de 1759, em que se extinguem todas as Escolas reguladas pelo método dos Jesuítas e se estabelece um novo regime. Diretor dos Estudos, Professores de Gramática Latina, de Grego e Retórica. In: ALVES, Gilberto Luiz. Educação e história em Mato Grosso: 1719-1864, 1984, pp. 113-114.

${ }^{48}$ Alvará régio, de 28 de junho de 1759, em que se extinguem todas as Escolas reguladas pelo método dos Jesuítas e se estabelece um novo regime. Diretor dos Estudos, Professores de Gramática Latina, de Grego e Retórica. In: ALVES, Gilberto Luiz. Educação e história em Mato Grosso: 1719-1864, 1984, p.115.

${ }^{49}$ Tendo por objetivo estatizar a Inquisição portuguesa, em defesa da ordem, contra as heresias, o Marquês de Pombal instituiu, pela Lei de 5 de abril de 1768, a Real Mesa Censória, cuja atuação seria importante no ambiente intelectual da época, diversificando-se em direções como: a instrução pública, o exame de livros nacionais ou estrangeiros que se pretendesse publicar ou simplesmente circular no país, entre outras. Mas, dos vários setores de atuação da Real Mesa Censória o aspecto mais interessante foi o da censura literária. FALCON, Francisco José Calazans. A época pombalina. Política econômica e monarquia ilustrada, 1982, pp. 442-443.

${ }^{50}$ Sob o galicanismo os monarcas consideravam que seus poderes temporais estavam fora da jurisdição papal. VIEIRA, David Gueiros. O protestantismo, a maçonaria e a questão religiosa no Brasil, 1980, p. 28.

${ }^{51}$ Os estudos de Teologia Moral, entre os jesuítas, continuadores da tradição escolástica, foram desenvolvidos de forma fragmentária, mediante os 'casos de consciência'. No Seminário de Olinda, a busca de princípios que ordenassem os estudos e os debates de casos, expressava uma crítica ao pensamento tradicionalmente encarnado na escolástica. ALVES, Gilberto Luiz. O Seminário de Olinda. In: LOPES, Eliane Marta T. et. al. 500 anos de educação no Brasil, 2003 , p. 71.

${ }^{52}$ De acordo com os Estatutos de D. Frei Manuel da Cruz (1760), seria feriado o dia do “(...) glorioso Santo Inácio de Loyola (...)”. TRINDADE, Raimundo. Arquidiocese de Mariana. Subsídios para sua história, 1953, v. 1, p. 388. 
${ }^{53}$ Estatutos para o Regimento do Seminário Menor de Nossa Senhora da Boa Morte (1760). TRINDADE, Raimundo. Arquidiocese de Mariana. Subsídios para sua história, 1953, v. 1, p. 386.

${ }^{54}$ Projeto de um Colégio de Artes e Disciplinas Eclesiásticas no edifício do Seminário (1816). TRINDADE, Raimundo. Arquidiocese de Mariana. Subsídios para sua história, 1953, v. 1, p. 394.

55 Declaração do Padre José Nogueira a respeito de Luís Vieira da Silva, seu aluno e futuro inconfidente (1752). TRINDADE, Raimundo. Arquidiocese de Mariana. Subsídios para a sua história, 1955, v.2, p. 61.

${ }^{56}$ Estatutos para o Regime do Seminário Episcopal de Nossa Senhora da Boa Morte, da Leal Cidade de Mariana, no Ano de 1821. Pasta de D. Frei José da Santíssima Trindade. Armário 2. Gaveta 2. Arquivo Eclesiástico da Arquidiocese de Mariana.

${ }^{57}$ Estatutos para o Regime do Seminário Episcopal de Nossa Senhora da Boa Morte, da Leal Cidade de Mariana, no Ano de 1821. Pasta de D. Frei José da Santíssima Trindade. Armário 2. Gaveta 2. Arquivo Eclesiástico da Arquidiocese de Mariana.

${ }^{58}$ No Motu Próprio Summorum Pontificum, de 07 de julho de 2007, o papa Bento XVI, com a intenção de trazer de volta ao seio da Igreja Católica o clero e os fiéis tradicionalistas, permite e incentiva o uso do Missal Romano de 1962, de João XXIII, para celebração de missas e sacramentos em latim. Como motivação para preservação de uma cultura que está se perdendo, o gesto pode ser louvado. Mas, se for apenas um retrocesso para fazer a igreja voltar às sacristias e falar uma linguagem não compreendida pelo povo, então é muito preocupante para aqueles que ainda acreditam que a igreja católica, principalmente em países do terceiro mundo, apoiada numa teologia de libertação, possa lutar contra as opressões.

${ }^{59}$ Estatutos para o Regime do Seminário Episcopal de Nossa Senhora da Boa Morte, da Leal Cidade de Mariana, no Ano de 1821. Pasta de D. Frei José da Santíssima Trindade. Armário 2. Gaveta 2. Arquivo Eclesiástico da Arquidiocese de Mariana.

${ }^{60}$ Estatutos para o Regime do Seminário Episcopal de Nossa Senhora da Boa Morte, da Leal Cidade de Mariana, no Ano de 1821. Pasta de D. Frei José da Santíssima Trindade. Armário 2. Gaveta 2. Arquivo Eclesiástico da Arquidiocese de Mariana.

${ }^{61}$ Estatutos para o Regime do Seminário Episcopal de Nossa Senhora da Boa Morte, da Leal Cidade de Mariana, no Ano de 1821. Pasta de D. Frei José da Santíssima Trindade. Armário 2. Gaveta 2. Arquivo Eclesiástico da Arquidiocese de Mariana.

${ }^{62}$ Estatutos para o Regime do Seminário Episcopal de Nossa Senhora da Boa Morte, da Leal Cidade de Mariana, no Ano de 1821. Pasta de D. Frei José da Santíssima Trindade. Armário 2. Gaveta 2. Arquivo Eclesiástico da Arquidiocese de Mariana.

${ }^{63}$ Estatutos para o Regime do Seminário Episcopal de Nossa Senhora da Boa Morte, da Leal Cidade de Mariana, no Ano de 1821. Pasta de D. Frei José da Santíssima Trindade. Armário 2. Gaveta 2. Arquivo Eclesiástico da Arquidiocese de Mariana.

${ }^{64}$ No contexto do século XVIII, também denominado "Século das Luzes", na Europa, a Igreja Católica enfraquece, diante de suas divisões internas; das críticas ao cristianismo e da intrusão do Estado. Nesse cenário, o filósofo francês François Marie-Arouet, cognominado Voltaire, não obstante deísta comandava o ataque à Igreja. MOUSNIER, Roland; LABROUSSE, Ernest. O século XVIII. O último século do Antigo Regime. In: CROUZET, Maurice (Dir.). História geral das civilizações, 1957, v. XI p. 91.

${ }^{65}$ Guillaume Raynal, pensador francês que deixou o hábito jesuíta para se dedicar à Filosofia e à História, publicou, em 1770, a obra: Histoire philosophique et politique des établissements e du commerce des européens dans les deux Indes, na qual combate as bases do Antigo Regime, entre as quais, a colonização. Grande Enciclopédia Delta-Larousse, 1973, p. 5689.

${ }^{66}$ Estatutos para o Regime do Seminário Episcopal de Nossa Senhora da Boa Morte, da Leal Cidade de Mariana, no Ano de 1821. Pasta de D. Frei José da Santíssima Trindade. Armário 2. Gaveta 2. Arquivo Eclesiástico da Arquidiocese de Mariana.

${ }^{67}$ Nasceu em Vila Rica, onde foi batizado em 1803. Fez seus estudos no Seminário de Nossa Senhora da Boa Morte, ordenando-se de presbítero em 1826. Foi professor de Retórica no referido Seminário e Vice-diretor Geral da Instrução Pública. Secretário do Governo da Província de Minas. Deputado à Assembleia Legislativa Provincial, de 1835 a 1837 e de 1846 a 1853. Deputado à Assembleia Geral, de 1834 a 1837. Faleceu em Mariana, em 1856. TRINDADE, Raimundo. Arquidiocese de Mariana. Subsídios para sua história, 1953, v.1, pp. 337-338.

${ }^{68}$ Edital sobre o Seminário de Nossa Senhora da Boa Morte de Mariana (1764). TRINDADE, Raimundo. Arquidiocese de Mariana. Subsídios para sua história., 1929, v. 2, p 776.

${ }^{69}$ Estatutos para o Regime do Seminário Episcopal de Nossa Senhora da Boa Morte, da Leal Cidade de Mariana, no Ano de 1821. Pasta de D. Frei José da Santíssima Trindade. Armário 2. Gaveta 2. Arquivo Eclesiástico da Arquidiocese de Mariana.

${ }^{70}$ Estatutos para o Regime do Seminário Episcopal de Nossa Senhora da Boa Morte, da Leal Cidade de Mariana, no Ano de 1821. Pasta de D. Frei José da Santíssima Trindade. Armário 2. Gaveta 2. Arquivo Eclesiástico da Arquidiocese de Mariana. 
${ }^{71}$ Estatutos para o Regime do Seminário Episcopal de Nossa Senhora da Boa Morte, da Leal Cidade de Mariana, no Ano de 1821. Pasta de D. Frei José da Santíssima Trindade. Armário 2. Gaveta 2. Arquivo Eclesiástico da Arquidiocese de Mariana.

${ }^{72}$ Estatutos para o Regime do Seminário Episcopal de Nossa Senhora da Boa Morte, da Leal Cidade de Mariana, no Ano de 1821. Pasta de D. Frei José da Santíssima Trindade. Armário 2. Gaveta 2. Arquivo Eclesiástico da Arquidiocese de Mariana.

${ }^{73}$ Estatutos para o Regime do Seminário Episcopal de Nossa Senhora da Boa Morte, da Leal Cidade de Mariana, no Ano de 1821. Pasta de D. Frei José da Santíssima Trindade. Armário 2. Gaveta 2. Arquivo Eclesiástico da Arquidiocese de Mariana.

${ }^{74}$ Estatutos para o Regime do Seminário Episcopal de Nossa Senhora da Boa Morte, da Leal Cidade de Mariana, no Ano de 1821. Pasta de D. Frei José da Santíssima Trindade. Armário 2. Gaveta 2. Arquivo Eclesiástico da Arquidiocese de Mariana.

${ }^{75}$ As Constituições do Arcebispado da Bahia tiveram validade jurídica até o Concílio Plenário Latino-americano, realizado em 1899. FRAGOSO, Hugo. Uma contribuição para a história vocacional da província franciscana de Santo Antônio. In: AZZI, Riolando (Org.). A vida religiosa no Brasil. Enfoques históricos, 1983, p. 172.

${ }^{76}$ Relatório do Episcopado de Mariana (Governo de D. Frei Manuel da Cruz) para a Sagrada Congregação do Concílio de Trento (1757). Pasta de D. Frei Manuel da Cruz. Armário 1. Gaveta 1. Arquivo Eclesiástico da Arquidiocese de Mariana.

${ }^{77}$ Não houve mais Externato no Seminário de Mariana, a partir do momento em que este foi confiado aos padres da Congregação da Missão, na segunda metade do século XIX. TRINDADE, Raimundo. Arquidiocese de Mariana. Subsídios para sua história, 1955, v.2, p. 366.

${ }^{78}$ Livro de Matrículas do Seminário de Nossa Senhora de Boa Morte (1792-1848). Armário IV. Arquivo Eclesiástico da Arquidiocese de Mariana.

${ }^{79}$ Constituído dos cônegos e funcionários da diocese de Mariana, e com os quais o primeiro bispo acreditava poder estruturar a administração de seu bispado. O Cabido era composto por catorze canonicatos, incluindo as dignidades de arcediago, arcipreste, chantre e tesoureiro mor. FREITAS, José Higino de. Aplicação no Brasil do decreto tridentino sobre os seminários até 1889, 1979, p. 57.

${ }^{80}$ Alvará de 2 de maio de 1747. TRINDADE, Raimundo. Arquidiocese de Mariana. Subsídios para sua história, 1953, v.1, p. 300.

${ }^{81}$ Edital sobre o Seminário de Nossa Senhora da Boa Morte de Mariana (1764). TRINDADE, Raimundo. Arquidiocese de Mariana. Subsídios para sua história, 1929, v. 2, p 776.

${ }^{82}$ Entre tais administrações, o Seminário de Mariana foi regido pelo padre José de Sousa Fernandes, sucessor de Trigo, a partir de 1770. TRINDẢDE, Raimundo. Arquidiocese de Mariana. Subsídios para sua história, 1953, v.1, p. 420.

${ }^{83}$ Pastoral sobre o Seminário (1772). TRINDADE, Raimundo. Arquidiocese de Mariana. Subsídios para sua história, 1929, v.2, p. 188.

${ }^{84}$ Nasceu em Lisboa, em 1714. Ordenou-se de subdiácono, permanecendo por longos anos nesta ordem. Doutor em Direito Civil e Eclesiástico, formado em Coimbra, em 1740. Era cônego da Sé patriarcal e desempenhava a função de Juiz de Nunciatura Apostólica em Lisboa, quando, em 1770, foi ordenado de presbítero. Nesta época, provavelmente já teria sido nomeado bispo de Mariana. Sua apresentação foi subscrita pelo Marquês de Pombal. Confirmado por Clemente XIV, em 1771, tomou posse perante o Cabido, por D. Francisco Xavier da Rua, seu procurador. O episcopado de D. Figueroa foi rápido, pois, em abril de 1772, foi transferido para o Arcebispado da Bahia. Entretanto, continuou na administração da diocese de Mariana até 1773, exercendo o governo pelo seu supracitado procurador. Faleceu em 1788. TRINDADE, Raimundo. Arquidiocese de Mariana. Subsídios para sua história, 1953, v.1, pp. 146-147.

${ }^{85}$ Nasceu em Cercosa, bispado de Coimbra, em 1720. Pertencia ao clero secular. Transferido de Macau por Clemente XIV, em 1772, tomou posse da diocese de Mariana por D. Francisco Xavier da Rua, seu procurador. Assim como D. Joaquim Borges Figueiroa, D. Bartolomeu Manuel Mendes dos Reis não veio à referida diocese, governando-a de Lisboa, por intermédio de seus procuradores: o supracitado Rua, desde a posse até 1775; o Dr. José Justino de Oliveira Gondim, de 1775 até 1778 e daí até a posse de seu sucessor, Inácio Correia de Sá, em 1779. Faleceu em Lisboa, em 1799. TRINDADE, Raimundo. Arquidiocese de Mariana. Subsídios para sua história,1953, v.1, pp. 147-148; 150.

${ }^{86}$ Antes da época prevista para a ordenação, o candidato devia submeter-se a um processo canônico de investigação acerca de suas origens e costumes, denominado "de genere et moribus". Dispondo da aprovação das autoridades eclesiásticas, isto é, tanto do vigário de sua paróquia de batismo, incumbido de ouvir a s testemunhas convocadas, quanto dos detentores de cargos formais na divisão do trabalho diocesano, o futuro sacerdote teria que providenciar seu título de patrimônio, transferindo à propriedade eclesiástica, um dado montante de capital, sob a forma de terras, imóveis, e outros bens de raíz. MICELI, Sérgio. A elite eclesiástica brasileira, 1988, pp. 113-114.

${ }^{87}$ Nasceu em São Sebastião da Pedreira, freguesia de Lisboa, em 1743. Recebeu as ordens sacerdotais em 1768. Professor de Sagrada Escritura; de Filosofia e de Teologia no Convento de São Pedro de Alcântara. Mestre em Teologia Dogmática e Moral. Pregador da corte na capela de Bemposta. Em 1796 foi nomeado bispo de Mariana, e confirmado, por Pio VI, no ano seguinte. Em 1798, D. Cipriano tomou posse, por Antônio Álvares Ferreira, seu procurador. E, no mesmo ano, fez sua entrada solene na catedral de Mariana, cidade onde faleceu em 1817. TRINDADE, Raimundo. Arquidiocese de Mariana. 
Subsídios para sua história, 1953, v.1, pp. 160-162.

${ }^{88}$ Termos de Ordenações (1801-1837). Armário IV. Arquivo Eclesiástico da Arquidiocese de Mariana.

${ }^{89}$ Termos de Ordenações (1749-1793). Armário IV. Arquivo Eclesiástico da Arquidiocese de Mariana.

${ }^{90}$ Por outro lado a má conduta de alguns sacerdotes não poderia ser compreendida como uma crítica às condições de existência no interior do Brasil, às condições de vida do baixo clero. Ver CALDEIRA, Jorge (Org.) Diogo Antônio Feijó. Formadores do Brasil, 1999.

${ }^{91}$ Referência aos estudiosos estrangeiros que estiveram no Brasil, no início do século XIX, tais como: Saint-Hilaire, Mawe e Martius. CARRATO, José Ferreira. Igreja, iluminismo e escolas mineiras coloniais, 1968, p. 59.

${ }^{92}$ Edital de D. Frei Cipriano de São José sobre o Seminário (1800). TRINDADE, Raimundo. Arquidiocese de Mariana. Subsídios para sua história, 1955, v. 2, p. 399.

${ }^{93}$ Relatório de D. Frei José da Santíssima Trindade (1827). Pasta de D. Frei José da Santíssima Trindade. Armário 1. Gaveta 2. Arquivo Eclesiástico da Arquidiocese de Mariana.

${ }^{94}$ Carta de D. Frei José da Santíssima Trindade ao Ministro Thomaz Antônio de Vila Nova Portugal (1820). TRINDADE, Raimundo. Arquidiocese de Mariana. Subsídios para sua história, 1929, v.2, p. 787.

${ }^{95}$ Carta de D. Frei José da Santíssima Trindade ao Ministro Thomaz Antônio de Vila Nova Portugal (1820). TRINDADE, Raimundo. Arquidiocese de Mariana. Subsídios para sua história, 1929, v.2, p. 787.

${ }^{96}$ O bispo refere-se ao primeiro Banco do Brasil, criado pelo Alvará Real de 12 de outubro de 1808. VIEIRA, Dorival Teixeira. Política financeira - o primeiro Banco do Brasil. In: HOLANDA, Sérgio Buarque de (Dir.). História Geral da Civilização Brasileira. O processo de emancipação, t.II, v.3, p. 124.

${ }^{97}$ Carta de D. Frei José da Santíssima Trindade ao Ministro Thomaz Antônio de Vila Nova Portugal (1820). TRINDADE, Raimundo. Arquidiocese de Mariana. Subsídios para sua história, 1929, v.2, p. 787.

${ }^{98}$ Relatório de D. Frei José da Santíssima Trindade (1827). Pasta De D. Frei José Da Santíssima Trindade. Armário 1. Gaveta 2. Arquivo Eclesiástico da Arquidiocese de Mariana.

${ }^{99}$ Estatutos para o Regime do Seminário Episcopal de Nossa Senhora da Boa Morte, da Leal Cidade de Mariana, no Ano de 1821. Pasta de D. Frei José da Santíssima Trindade. Armário 2. Gaveta 2. Arquivo Eclesiástico da Arquidiocese de Mariana.

${ }^{100}$ Carta de D. Frei José da Santíssima Trindade ao Núncio Apostólico (1830). TRINDADE, Raimundo. Arquidiocese de Mariana. Subsídios para sua história, 1953, v.1, pp. 401-402.

${ }^{101}$ O Seminário de Mariana em 1831. Revista do Arquivo Público Mineiro. Ano IV, 1899.

${ }^{102}$ Nasceu em São Paulo, em 1784. Ordenou-se sacerdote em 1805. Em 1821, foi eleito deputado para as Cortes Constitucionais, em Lisboa, sendo perseguido pela Corôa portuguesa, por suas ideias separatistas. Refugia-se na Inglaterra e retorna ao Brasil, após a independência. Deputado, ministro da Justiça e senador. Em 1835 torna-se regente do Brasil, porém seu governo foi conturbado, ou seja, marcado por revoltas. Sem uma base de apoio, foi obrigado a renunciar em 1837. Em 1842 participou da Revolução Liberal em São Paulo, mas foi derrotado e preso. Libertado em 1843, passa a viver no Espírito Santo. Doente, volta para São Paulo, onde morre nesse mesmo ano. Almanaque Abril. Quem é quem na história do Brasil, 2000, p. 204.

${ }^{103}$ Natural de Minas Novas, norte de Minas. Exercia o cargo de vigário colado de São Domingos de Araçuaí, quando foi nomeado bispo de Mariana, pelo governo regencial, em 1838. Foi confirmado, em 1840, por Gregório XVI, porém adoeceu na Vila de São José, e faleceu em 1841, sem tomar posse. Foi sepultado na Igreja da Ordem Terceira, de São João del Rei. TRINDADE, Raimundo. Arquidiocese de Mariana. Subsídios para sua história, 1953, v.1, p. 214.

${ }^{104}$ Raimundo Trindade, segundo ele próprio, copiou tal informação de um dos cadernos de D. Silvério Gomes Pimenta (1892-1894). TRINDADE, Raimundo. Arquidiocese de Mariana. Subsídios para sua história, 1953, v.1, p. 221.

${ }^{105}$ Tal relato também foi transcrito do referido caderno. TRINDADE, Raimundo. Arquidiocese de Mariana. Subsídios para sua história, 1953, v.1, p. 221.

${ }^{106}$ Pastoral de D. Antônio Ferreira Viçoso aos Filhos do Colégio Episcopal. PIMENTA, Silvério Gomes. Vida de D. Antônio Ferreira Viçoso, 1920, p. 111.

${ }^{107}$ Indo de carruagem por Belém, D. José I foi alvejado por tiros de carabina que quase o mataram. Logo depois, o ministro Marquês de Pombal, mandou prender os possíveis mentores do atentado: os Marqueses de Távora, o Duque de Aveiro e outros fidalgos. No ano seguinte, saiu a sentença: a Marquesa de Távora foi decapitada; o Marquês de Távora e o Duque de Aveiro foram triturados em uma roda, com golpes de macete. Outros nobres também foram supliciados. CALMON, Pedro. História do Brasil, 1959, v. 4, pp. 1148; 1150. Suspeitou-se que o Irmão Lourenço de Nossa Senhora, seria D. Carlos de Mendonça Távora, cuja família estava envolvida na supracitada tentativa de regicídio, e que veio para o Brasil fugido da perseguição de Pombal. Porém, de acordo com Trindade, tal suspeita parece infundada, ao se consultar o Testamento do Irmão Lourenço, o qual ele mesmo declara: “(...) sou natural de Nagoselo, termo de São João da Pesqueira, Bispado de Lamego, filho legítimo de Antônio Pereira e sua mulher Ana de Figueiredo (...) vivi no estado de solteiro e nunca tive filhos (...).”.Daí seria difícil acreditar que o Irmão Lourenço mentisse, e de modo injustificável. TRINDADE, Raimundo. Arquidiocese de Mariana. Subsídio para sua história, 1955, v.2, p. 12. 
${ }^{108}$ Cópia do Testamento do Irmão Lourenço (1806). Pasta de D. Frei Cipriano de São José. Armário 2. Gaveta 1. Arquivo Eclesiástico da Arquidiocese de Mariana.

${ }^{109}$ Carta Régia (1820). TRINDADE, Raimundo. Arquidiocese de Mariana. Subsídios para sua história, 1929, v.2, pp.930-931.

${ }^{110}$ Regimento do Colégio do Caraça. Capítulo IV, § 1. ZICO, José Tobias. Caraça, peregrinação, cultura e turismo, 1988, p. 42.

${ }^{111}$ Nasceu em São Miguel do Piracicaba, Minas Gerais, em 1859, e faleceu em 1933. Também foi escritor e publicista e, entre suas obras, destaca-se: Sítios e personagens. TRINDADE, Raimundo. Arquidiocese de Mariana. Subsídios para sua história, 1955, v. 2, p. 208.

${ }^{112}$ Nasceu em Brumado do Mato Dentro, em 1865, e morreu em Mariana, em 1916. Como sacerdote, deu grande impulso ao ensino da doutrina cristã. TRINDADE, Raimundo. Arquidiocese de Mariana. Subsídios para sua história, 1955, v. 2 , p. 212.

${ }^{113}$ Afonso Augusto Moreira Pena nasceu em Santa Bárbara, Minas Gerais, em 1847. Formou-se em Direito em São Paulo. Deputado provincial; foi chefe dos seguintes ministérios: da Guerra, da Agricultura, e da Justiça. Presidente de sua província natal. Promulgou a lei que transferiu a capital mineira, de Ouro Preto para Curral del Rei, onde foi construída a cidade de Belo Horizonte. Eleito presidente da República, com o apoio das oligarquias paulista e mineira, para o quatriênio 1906-1910. Porém, faleceu em 1909, no Rio de Janeiro, vitimado por uma pneumonia, não completando o mandato. Almanaque Abril. Quem é quem na história do Brasil, 2000, p. 375.

${ }^{114}$ Artur da Silva Bernardes nasceu em Viçosa, Minas Gerais, em 1875. Formou-se em Direito em São Paulo. Casou-se com a filha de um importante político da região de Viçosa, e tornou-se herdeiro político do sogro. Deputado estadual, federal, e presidente de Minas. Ocupou a presidência da República, entre 1922 e 1926. Seu governo foi conturbado, marcado por revoltas tenentistas. Faleceu em 1955, no Rio de Janeiro. Almanaque Abril. Quem é quem na história do Brasil, 2000, p.108.

${ }^{115}$ Nasceu em 1890, em Bom Jesus do Amparo, freguesia da diocese de Mariana. Era descendente de uma família de fazendeiros e políticos de Caeté, Minas Gerais. Seu bisavô, José Teixeira da Fonseca Vasconcelos, Visconde de Caeté, foi o primeiro presidente da Província de Minas, em 1824 e 1827. Após ter sido vereador de Caeté, Carlos Carmelo de Vasconcelos Mota ingressou no Seminário de Mariana, onde se ordenou sacerdote, em 1918. Mais tarde, foi cardeal de São Paulo. TRINDADE. Raimundo. Arquidiocese de Mariana. Subsídios para sua história, 1955, v.2, p. 217. Faleceu em Aparecida, São Paulo, em 1982. BELLOCH, Ismael. \& ABREU, Alzira Alves de. Dicionário histórico e biográfico brasileiro (1930-1983), 1984, p. 1763.

${ }^{116}$ Delfim Moreira Moreira nasceu em 1868, em Cristina, Minas Gerais. Era filho de fazendeiro. Formou-se em Direito em São Paulo. Vereador, deputado estadual, presidente da Província de Minas. Eleito vice-presidente da República, ocupa a presidência, em 1918, no lugar do titular, Francisco de Paula Rodrigues Alves, o qual morreu vitimado pela gripe espanhola. Faleceu em 1920, em Santa Rita do Sapucaí, Minas Gerais. Almanaque Abril. Quem é quem na história do Brasil, 2000, p. 338.

${ }^{117}$ Em 1827, estando o padre Leandro Peixoto em missão pelos sertões de Uberaba, no Triângulo Mineiro, um casal sem filhos faz doação de uma fazenda ao Colégio do Caraça. Tal doação foi confirmada solenemente em 1830, com o ônus de se erigir ali uma capela e uma escola pública de primeiras letras. TRINDADE. Raimundo. Arquidiocese de Mariana. Subsídios para sua história, 1955, v.2, p. 15.

${ }^{118}$ Em 1827, D. Pedro I, então imperador do Brasil, confiou aos lazaristas a administração do Santuário de Congonhas, onde fundaram um colégio e o mantiveram por aproximadamente trinta anos. TRINDADE. Raimundo. Arquidiocese de Mariana. Subsídios para sua história, 1955,v.2, p. 15.

${ }^{119}$ Essa informação consta no Ofício de D. Antônio Maria Correia de Sá e Benevides, bispo de Mariana, ao Conselheiro Antônio da Costa Pinto e Silva (1877). TRINDADE. Raimundo. Arquidiocese de Mariana. Subsídios para sua história, 1953, v.1, p. 410.

${ }^{120}$ Nas primeiras décadas da segunda metade do século XIX, o Seminário da Bahia e o Seminário de Diamantina também foram dirigidos pelos padres da Congregação da Missão. FREITAS, José Higino de. Aplicação no Brasil do decreto tridentino sobre os seminários até 1889, 1979, pp.229; 231.

${ }^{121}$ Provisão da entrega do Seminário de Mariana aos Padres da Congregação da Missão (1863). TRINDADE. Raimundo. Arquidiocese de Mariana. Subsídios para sua história, 1929, v.2, p. 854.

Recebido: novembro/13 $\quad$ Aprovado: março/14 